\title{
Regulation of Pituitary Cocaine- and Amphetamine-Regulated Transcript Expression and Secretion by Hypothalamic Gonadotropin- Releasing Hormone in Chickens
}

\author{
Chunheng $M o^{1,2}$, Can $L v^{1}$, Long Huang ${ }^{1}$, Zhengyang $L i^{1}$, Jiannan Zhang ${ }^{1}$, Juan $L i^{1}$ and \\ Yajun Wang ${ }^{1 *}$
}

${ }^{1} K e y$ Laboratory of Bio-resources and Eco-environment, Ministry of Education, College of Life Sciences, Sichuan University, Chengdu, China, ${ }^{2}$ Key Laboratory of Birth Defects and Related Diseases of Women and Children, Ministry of Education,

West China Second University Hospital, Sichuan University, Chengdu, China

OPEN ACCESS

Edited by:

Krystyna Pierzchala-Koziec, University of Agriculture of Krakow,

Poland

Reviewed by:

Takeshi Ohkubo,

Ibaraki University, Japan

Xiquan Zhang,

South China Agricultural University,

China

*Correspondence:

Yajun Wang

cdwyjhk@gmail.com

Specialty section: This article was submitted to

Avian Physiology,

a section of the journal

Frontiers in Physiology

Received: 20 December 2018

Accepted: 24 June 2019

Published: 25 July 2019

Citation:

Mo C, Lv C, Huang L, Li Z, Zhang J, Li J and Wang Y (2019) Regulation of

Pituitary Cocaine- and Amphetamine-

Regulated Transcript Expression and Secretion by Hypothalamic

Gonadotropin-Releasing Hormone in Chickens.

Front. Physiol. 10:882.

do: 10.3389/fphys.2019.00882
There is increasing evidence that cocaine- and amphetamine-regulated transcript (CART) peptide is abundantly expressed in the anterior pituitary of birds and mammals, suggesting that CART peptide may be a novel pituitary hormone and its expression and secretion is likely controlled by the hypothalamic factor(s). To substantiate this hypothesis, using chicken as an animal model, we examined the effects of gonadotropin-releasing hormone $(\mathrm{GnRH})$ on pituitary CART secretion and expression and investigated whether GnRH could modulate plasma CART levels. The results showed that: (1) chicken $\mathrm{GnRH}(\mathrm{GnRH} 1$ and $\mathrm{GnRH} 2)$ could potently stimulate CART peptide secretion in intact pituitaries incubated in vitro, as detected by Western blot; (2) $\mathrm{GnRH}$ could also stimulate CART mRNA expression in cultured pituitary cells, as revealed by quantitative real-time polymerase chain reaction (qPCR) assay; (3) GnRH actions on pituitary CART expression and secretion are likely mediated by $\mathrm{GnRH}$ receptor coupled to the intracellular $\mathrm{Ca}^{2+}$, MEK/ERK, and cAMP/PKA signaling pathways; and (4) plasma CART levels are high in chickens at various developmental stages $(1.2-3.5 \mathrm{ng} / \mathrm{ml})$ and show an increasing trend towards sexual maturity, as detected by enzyme-linked immunosorbent assay (ELISA). Moreover, plasma CART levels could be significantly induced by intraperitoneal administration of $\mathrm{GnRH}$ in chicks. Taken together, our data provide the first collective evidence that CART peptide is a novel pituitary hormone and its expression and secretion are tightly controlled by hypothalamic $\mathrm{GnRH}$, thus likely being an active player in the hypothalamic-pituitary-gonadal (HPG) axis.

Keywords: pituitary, cocaine- and amphetamine-regulated transcript, hypothalamus, gonadotropin-releasing hormone, chicken

\section{INTRODUCTION}

It is well documented that cocaine- and amphetamine-regulated transcript (CART), an anorectic peptide of 41- or 48-amino acids with three intra-molecular disulfide bonds, plays an important role in the regulation of feeding and energy balance in mammals (Rogge et al., 2008). CART peptide encoded by CART gene was first discovered in abundance in the rat hypothalamus, 
in which it may act as a downstream effector of leptin with potent appetite-suppressing activity (Douglass et al., 1995; Gautvik et al., 1996; Kristensen et al., 1998; Elias et al., 2001). Besides the hypothalamus, CART is also expressed in other brain regions, the peripheral nervous system (PNS) and peripheral tissues of mammals including the anterior pituitary, ovary, and pancreas (Koylu et al., 1997; Jensen et al., 1999; Thim et al., 1999; Murphy et al., 2000; Kobayashi et al., 2004; Wierup et al., 2006; Ma et al., 2016), and is suggested to be involved in the regulation of many other physiological processes, such as drug reward and reinforcement, stress, pancreatic secretion, bone remodeling, and ovarian follicle development and steroidogenesis (Kobayashi et al., 2004; Elefteriou et al., 2005; Sen et al., 2007; Rogge et al., 2008; Abels et al., 2016).

Besides being a local regulatory factor found in the central nervous system (CNS) and peripheral tissues, CART peptide is present in the blood at physiological levels in mammals. In humans, the levels of plasma CART were reported to be higher in patients with neuroendocrine malignancy (Bech et al., 2008). In rats and rhesus macaques, the levels of circulating CART display diurnal variations, which is partially influenced by the circulating corticosteroids (Stanley et al., 2004; Vicentic et al., 2004). Moreover, blood CART levels are also related to the energy balance status, such as pregnancy/lactation in rats (Vicentic et al., 2004; Smith et al., 2006; Vicentic, 2006).

Despite the detection of physiological level of circulating CART in various species, its source has remained controversial. Several studies have suggested that the anterior pituitary may be a source of circulating CART peptide in mammals (Stanley et al., 2004). In rodents, CART mRNA and protein are found in the anterior pituitary (Thim et al., 1999; Murphy et al., 2000). More recent studies revealed that CART may be expressed in the gonadotrophs, lactotrophs, corticotrophs, thyrotrophs, and/ or somatotrophs in rodents (Kuriyama et al., 2004; Stanley et al., 2004; Kappeler et al., 2006; Mortensen and Camper, 2016). In addition, pituitary CART secretion is reported to be under the control of hypothalamic factors such as corticotropin-releasing hormone $(\mathrm{CRH})$ and circulating corticosterone (Stanley et al., 2004; Vicentic et al., 2004; Kappeler et al., 2006). Furthermore, intraperitoneal administration of $\mathrm{CRH}$ is demonstrated to increase plasma CART levels in rats (Stanley et al., 2004). Taken together, these findings tend to support the idea that CART is a pituitary hormone, which is released into the circulation under the influence of hypothalamic factor(s) and peripheral signal (Stanley et al., 2004; Kappeler et al., 2006). Regrettably, this notion has received little attention till now.

Recently, we have identified chicken CART gene (also named CART1) which is an ortholog of mammalian CART (Cai et al., 2015; Mo et al., 2015), and it encodes a mature CART peptide of 41 or 48 amino acids, which shows a striking homology (94-98\% amino acid identity) with mammalian CART peptide (Cai et al., 2015). This suggests CART peptide may play important roles in chickens similar to their mammalian counterparts, such as inhibition of food intake (Tachibana et al., 2003; Honda et al., 2007). However, unlike mammalian CART abundantly expressed in the hypothalamus and pituitary (Rogge et al., 2008), chicken
CART is predominantly and abundantly expressed in the anterior pituitary (Cai et al., 2015). This interesting finding led us to hypothesize that in chickens, CART peptide is a novel pituitary hormone, which expression/secretion is regulated by hypothalamic factors such as $\mathrm{CRH}$ demonstrated in our recent study (Mo et al., 2015). To further substantiate this hypothesis, using chicken as the animal model, our present study aims to: (1) investigate the effect of other hypothalamic factors, e.g., gonadotropin-releasing hormone $(\mathrm{GnRH})$, on pituitary CART secretion and expression, and the involvement signaling pathways and (2) investigate whether $\mathrm{GnRH}$ affects plasma CART levels. Our findings represent the first to establish a clear concept that CART is a pituitary hormone, and its expression, secretion, and plasma levels are under the control of hypothalamic GnRH (GnRH1). Given that $\mathrm{GnRH}$ has a pivotal role in the reproduction of vertebrates including birds and mammals (Millar et al., 2004; Millar, 2005), our findings strongly suggest that CART peptide may also exert some influence on vertebrate reproduction.

\section{MATERIALS AND METHODS}

\section{Ethics Statement}

Chickens were purchased from local commercial companies. All animal experiments were performed according to the guidelines provided by the Animal Ethics Committee of Sichuan University.

\section{Chemicals, Hormones, Antibodies, and Primers}

Chicken GnRH1 and GnRH2 were synthesized using solidphase Fmoc chemistry (GL Biochem, Shanghai, China). The pharmacological agents including 2-aminoethoxydiphenyl borate (2-APB), nifedipine, U73122, thapsigargin, KN62, calmidazolium, phorbol-12-myristate-13-acetate (PMA), calphostin C, PD98059, MDL12330A, and H89 were purchased from Calbiochem (Merck KGaA, Darmstadt, Germany). Rabbit anti-CART polyclonal antibody (CART-H47, sc366086) was purchased from Santa Cruz Biotechnology Inc. (Dallas, TX) and the specificity of anti-CART antibody was validated by Western blot/immunofluorescent detection of CART-specific bands/signals in chicken pituitary (but not in chicken liver, duodenum, and testes, which lack target gene expression) (Cai et al., 2015) or in HEK293 cells transfected with chicken CART expression plasmid (Cai, MSc thesis 2015). The monoclonal antibodies for $\beta$-actin, phospho-ERK1/2, ERK1/2, and phospho-CREB were purchased from Cell Signaling Technology Inc. (CST, Beverly, MA). Donkey anti-rabbit IgG $(\mathrm{H}+\mathrm{L})$ cross adsorbed secondary antibody (Dylight 488 conjugate) was purchased from ThermoFisher Scientific (Waltham, MA). The polyclonal antibodies against recombinant full-length chicken GH and PRL were prepared in our laboratory (Huang et al., 2014; Meng et al., 2014; Bu et al., 2016). All primers were synthesized by Beijing Genome Institute (BGI, China) and listed in Table 1. 
TABLE 1 | Primers used in this study. ${ }^{a}$

\begin{tabular}{|c|c|c|c|}
\hline Gene & Sense/antisense & Primer sequence $\left(5^{\prime}-\right.$ to $\left.-3^{\prime}\right)$ & Size (bp) \\
\hline \multicolumn{4}{|c|}{ Primers for quantitative real-time RT-PCR assays } \\
\hline \multirow[t]{2}{*}{ CART } & Sense & CGTCCCGAGAGAAGGAGCTGATC & 123 \\
\hline & Antisense & АCTGCTCTCCGGCGTCGCACAT & \\
\hline \multirow[t]{2}{*}{$\mathrm{LH} \beta$} & Sense & TGCGGCCCCATAGAGCCATG & 229 \\
\hline & Antisense & GTGGTGGTCACAGCCATACA & \\
\hline \multirow[t]{2}{*}{ GnRHR1 } & Sense & GCATCACCCCAGCTATTTCTC & 253 \\
\hline & Antisense & GTGCCTTGGAGATGTGGTCAT & \\
\hline \multirow[t]{2}{*}{ GnRHR2 } & Sense & TCGCTGTGCCGCAGCTGTTC & 229 \\
\hline & Antisense & CTGGAGGAGAAGAGGCTGGAGC & \\
\hline \multirow[t]{2}{*}{$\mathrm{GH}$} & Sense & CAAGCAACACCTGAGCAACT & 83 \\
\hline & Antisense & CAGCGTGACCACAGCGATGA & \\
\hline$P R L$ & Sense & GCGGGTTCATTCTGGTGATGCT & 180 \\
\hline \multirow[t]{2}{*}{$\beta$-actin } & $\begin{array}{l}\text { Antisense } \\
\text { Sense }\end{array}$ & $\begin{array}{l}\text { TGGATTAGGCGGCACTTCAAA } \\
\text { CCCAGACATCAGGGTGTGATG }\end{array}$ & 123 \\
\hline & Antisense & GTTGGTGACAATACCGTGTTCAAT & \\
\hline \multicolumn{4}{|c|}{ Primers used for RT-PCR assays } \\
\hline \multirow[t]{2}{*}{ GnRHR1 } & Sense & GCATCACCCCAGCTATTTCTC & 253 \\
\hline & Antisense & GTGCCTTGGAGATGTGGTCAT & \\
\hline \multirow[t]{2}{*}{ GnRHR2 } & Sense & TCGCTGTGCCGCAGCTGTTC & 229 \\
\hline & Antisense & CTGGAGGAGAAGAGGCTGGAGC & \\
\hline \multirow[t]{2}{*}{$\beta$-actin } & Sense & TGTGCTACGTCGCACTGGAT & 401 \\
\hline & Antisense & GCTGATCCACATCTGCTGGA & \\
\hline \multicolumn{4}{|c|}{ Primers for constructing expression plasmids ${ }^{b}$} \\
\hline \multirow[t]{2}{*}{ GnRHR1 } & Sense & CCCAAGCTTCATGTGCGTACCAGCTGCT & 1,149 \\
\hline & Antisense & CCGGAATTCCTTCAGCACACCGTGTTAAC & \\
\hline \multirow[t]{2}{*}{ GnRHR2 } & Sense & CCCAAGCTTACATGGCCCGGCTCGGCG & 1,282 \\
\hline & Antisense & CCGGAATTCGCTCACAGCGCACTGCTCTG & \\
\hline
\end{tabular}

${ }^{a}$ All primers were synthesized by BGI (China).

${ }^{b}$ Restriction sites added in 5'-end of the primers are underlined.

\section{Quantitative Real-Time Polymerase Chain Reaction Assay}

Chicken anterior pituitaries were collected either for cell culture, or for total RNA extraction. Total RNA was extracted from chicken tissues or cultured pituitary cells using RNAzol (Molecular Research Center, Cincinnati, $\mathrm{OH}$ ) and reversely transcribed using M-MLV reverse transcriptase (TaKaRa). Reverse transcription (RT) samples were then used for quantitative real-time PCR ( $\mathrm{qPCR}$ ) assays to investigate the mRNA expression of target genes, as described in our recent studies (Cai et al., 2015; Mo et al., 2015).

\section{Detection of Cocaine- and Amphetamine- Regulated Transcript (CART) Expression in Chicken Pituitaries or Dispersed Pituitary Cells}

Anterior pituitaries collected from adult male chickens were fixed in $4 \%$ paraformaldehyde and embedded in paraffin wax. Immunohistochemical staining was performed in the pituitary sections, as described in our recent studies (Huang et al., 2014; $\mathrm{Bu}$ et al., 2016). Anti-CART (1:300) was used to probe the spatial distribution of CART in anterior pituitaries, as previously described (Mo et al., 2015). Sections incubated with rabbit pre-immune serum, instead of anti-CART, were used as negative controls. To probe the spatial distribution of pituitary CART mRNA, the anterior pituitaries collected from adult male chickens were washed with PBS. The cephalic lobe and caudal lobe were separated carefully by scalpels, and their respective tissue lysates and total RNA were prepared for qPCR assay of CART ( $L H \beta, G n R H R 2, G H$, or $P R L)$ expression respectively, as described in our recent studies (Huang et al., 2014; Mo et al., 2015).

As described in our recent studies (Bu et al., 2016; Mo et al., 2017), the dispersed pituitary cells from adult male chickens were cultured in Medium 199 supplemented with 15\% fetal bovine serum (Invitrogen) in a Corning Cell-BIND 48-well plates (Corning, Tewksbury, MA) at $37^{\circ} \mathrm{C}$ with $5 \% \mathrm{CO}_{2}$ at a density of $5 \times 10^{5}$ cells/well. After $4 \mathrm{~h}$ of culture, the pituitary cells were fixed in $4 \%$ paraformaldehyde and washed with PBS. Then, the cells were treated by $0.1 \%$ Triton-X-100 for $10 \mathrm{~min}$, washed with PBS, and incubated with the blocking buffer (1\% BSA in PBS) for $30 \mathrm{~min}$ at room temperature. After blocking, anti-CART (1:300), anti-GH (1:500), or anti-PRL (1:300) diluted in blocking buffer respectively, was added to each well and incubated at $4^{\circ} \mathrm{C}$ overnight. The cells were washed and incubated with the secondary antibody (1:300) for $1 \mathrm{~h}$ at room temperature. Finally, the pituitary cells were counterstained with $1 \mu \mathrm{g} / \mathrm{ml}$ DAPI and observed under a fluorescence microscope (Nikon ECLIPSE Ti). 
RNA-Seq Detection of CART, GnRHR1, and GnRHR2 mRNA Transcripts in Chick Hypothalamus and Anterior Pituitary

The mRNA levels of CART, GnRHR1, and GnRHR2 were examined by analyzing our RNA-Seq data of the hypothalamus and anterior pituitary from 1-week-old male chicks (Mo et al., unpublished data). The quantification of reads was performed with Salmon v0.8.2 (Patro et al., 2017) against the Ensembl database ${ }^{1}$. The transcripts per million (TPM) values were used to estimate the abundance of CART, GnRHR1, and GnRHR2 mRNA transcripts.

\section{Evaluation of GnRH1/GnRH2 Action on CART Secretion From Intact Pituitaries Incubated in vitro}

As described in our recent study (Huang et al., 2014), the intact anterior pituitaries collected from 1-week-old male chicks were washed with PBS and placed on a 48-well plate (NUNC) supplemented with $400 \mu \mathrm{l}$ serum-free Medium 199 (Invitrogen). After 1 -h incubation at $37^{\circ} \mathrm{C}$, the medium was replaced by $300 \mu \mathrm{l}$ serum-free Medium 199 containing different concentrations of chicken GnRH1 or GnRH2 (0.1-100 nM) and incubated for $4 \mathrm{~h}$. Then, CART peptide secreted into the incubation medium by the pituitaries was examined by Western blot using anti-CART antibody (1:300). Parallel blotting of $\beta$-actin and CART in pituitary tissue lysates was also conducted.

\section{Detection of CART Peptide Levels in Chicken Plasma by Enzyme-Linked Immunosorbent Assay}

To evaluate plasma CART peptide levels in chickens, blood samples were obtained from the wing vein of male chickens (2-week-old, 5-month-old, and 15-month-old) and collected in the vacutainer blood collection tubes with $\mathrm{K}_{2}$ EDTA. All samples were taken from each animal between 14:00 and 15:00. The blood samples were centrifuged at $1,600 \times g$ for $15 \mathrm{~min}$ at $4^{\circ} \mathrm{C}$, and plasma was collected and stored at $-80^{\circ} \mathrm{C}$ until use. The levels of CART peptide in chicken plasma was determined by a commercially available competitive enzymelinked immunosorbent assay (ELISA) kit (EK-003-61, Phoenix Pharmaceuticals, Inc.), which is designed to specifically detect the CART peptide based on the principle of competitive enzyme immunoassays.

To examine whether GnRH can elevate the plasma CART levels in vivo, male chicks (17-day-old) were intraperitoneally injected with $1 \mathrm{ml}$ of saline for 2 days to acclimatize them to the injection procedure. On the following day, chicks ( $n=7$ /group) were intraperitoneally injected with either saline or $5 \mu \mathrm{g} / \mathrm{chick}$ of $\mathrm{GnRH} 1$, and $30 \mathrm{~min}$ after the administration, blood was obtained from the wing vein of these chicks and collected in the vacutainer blood collection tubes with $\mathrm{K}_{2}$ EDTA as soon as possible. The levels of CART

${ }^{1}$ http://www.ensembl.org/Gallus_gallus peptide in chicken plasma was then determined by competitive ELISA assay.

\section{Investigation on the Effect of Chicken GnRH1/GnRH2 on CART Expression in Cultured Chick Pituitary Cells}

As described in our recent studies (Huang et al., 2014; Mo et al., 2015), anterior pituitaries collected from 1-week-old chicks were sliced and digested by $0.25 \%$ trypsin at $37^{\circ} \mathrm{C}$ for $20 \mathrm{~min}$. The dispersed pituitary cells were cultured at a density of $5 \times 10^{5}$ cells/well in Medium 199 supplemented with $15 \%$ fetal bovine serum in a Corning Cell BIND 48-well plates (Corning, Tewksbury, MA) at $37^{\circ} \mathrm{C}$ with $5 \% \mathrm{CO}_{2}$. After $24-\mathrm{h}$ culture, the medium was replaced with serum-free M199 medium and the cells were treated with chicken GnRH1/ GnRH2 for the duration (12-48 h) or with increasing doses (0.1-100 nM) of each peptide. The total RNA was then extracted from cultured pituitary cells and the expression of CART and $\beta$-actin assayed by qPCR.

\section{Functional Characterization of Chicken GnRHR1 and GnRHR2 in Cultured Chinese Hamster Ovary Cells}

Based on the reported cDNA sequences of chicken GnRHR1 and GnRHR2 (accession nos.: NM_204653; NM_001012609) (Sun et al., 2001; Shimizu and Bedecarrats, 2006), gene-specific primers were used to amplify the open reading frame from adult chicken anterior pituitaries using high-fidelity Taq DNA polymerase (TOYOBO, Japan). The amplified PCR products were cloned into the pcDNA3.1 (+) expression vector (Invitrogen) and sequenced. According to our previously established methods, the signaling property of each receptor was examined in Chinese hamster ovary ( $\mathrm{CHO}$ ) cells using pGL3-NFAT-RE-luciferase (Wang et al., 2012), pGL4-SREluciferase (Mo et al., 2015), and pGL3-CRE-luciferase reporter systems (Wang et al., 2007).

\section{Data Analysis}

The relative mRNA levels of CART (or other genes) in pituitary cells (or pituitary) were first calculated as the ratios to that of $\beta$-actin and then expressed as the percentage compared to their respective controls. The data were analyzed by the Student's $t$-test (between two groups) or by one-way ANOVA followed by the Dunnett test in GraphPad Prism 5 (GraphPad Software, San Diego, CA). To validate our results, all experiments were repeated at least three times.

\section{RESULTS}

\section{Detection of Cocaine- and Amphetamine- Regulated Transcript (CART) Peptide in Chicken Anterior Pituitary and Plasma}

Using immunohistochemical staining (IHC), we first examined the spatial distribution of CART in the anterior pituitary 
of adult male chicken. As shown in Figure 1A, CART-ir cells were densely distributed in cephalic (Ce) and caudal (Ca) lobes, as previously reported (Mo et al., 2015). Using immunofluorescence (IF) assay (Mo et al., 2017), we further revealed that CART-ir cells made up $\sim 12.3 \%$ of the shortterm cultured dispersed pituitary cells (Figures 1B,C). As a control, somatotrophs (GH cells) and lactotrophs (PRL cells) made up $\sim 12.8$ or $\sim 8.5 \%$ of the cells under the same condition (Figure 1C).

The extremely high expression level of CART and the high proportion of CART-ir cells within the anterior pituitary led us to propose that like GH and PRL, CART can be released into the circulation. As expected, a high concentration $(1.2-3.5 \mathrm{ng} / \mathrm{ml})$ of CART was detected in the plasma of male chickens at different developmental stages by ELISA (Figure 1D). As shown in Figure 1D, a significant increase in plasma CART levels was noted from the pre-pubertal stage (2-week-old, $1.2 \mathrm{ng} / \mathrm{ml}$ ) to sexually mature stages (5-month-old, $2.8 \mathrm{ng} /$ $\mathrm{ml}$; 15 -month-old, $3.5 \mathrm{ng} / \mathrm{ml}$ ). The remarkably high levels of plasma CART, together with the predominant expression of CART in anterior pituitaries, strongly support our hypothesis that CART is a pituitary hormone which is released into the circulation under the control of hypothalamic factors in chickens (Cai et al., 2015; Mo et al., 2015).

\section{Gonadotropin-Releasing Hormone (GnRH) Stimulates Pituitary CART Secretion and Elevates Plasma CART Levels}

Since the spatial distribution of CART detected by qPCR within anterior pituitaries is much similar to that of $L H \beta$ (Proudman et al., 1999; Scanes, 2015) and different from that of GH/PRL (Figure 1E), it led us to hypothesize that like pituitary LH (Sharp et al., 1986, 1987), CART secretion is likely controlled by the hypothalamic GnRH in chickens. To test this hypothesis, the effects of two chicken GnRHs (GnRH1 and GnRH2) on CART peptide release were examined both in vitro and in vivo. As shown in Figure 2, GnRH1 and GnRH2 (0-100 nM, $4 \mathrm{~h})$ potently stimulated the secretion of mature CART peptide with a molecular weight of $\sim 5 \mathrm{kDa}$ (41/48 amino acids) in intact pituitaries incubated in vitro, with the minimal effective concentration observed at $1 \mathrm{nM}$, as revealed by Western blot. In agreement with this finding, intraperitoneal injection of GnRH1 (5 $\mu \mathrm{g} / \mathrm{chick}, 30 \mathrm{~min}$ ) caused a two-fold or higher increase (1.3 vs. $2.7 \mathrm{ng} / \mathrm{ml}$, $p<0.05)$ in plasma CART levels in vivo, as monitored by ELISA (Figure 3). These findings clearly indicate that $\mathrm{GnRH}$ can potently stimulate pituitary CART secretion and elevate circulating CART levels effectively.

To determine whether the two identified chicken GnRH receptors (GnRHR1 and GnRHR2) are involved in mediating GnRH action on pituitary CART secretion, we examined their expression in the $\mathrm{Ce}$ and $\mathrm{Ca}$ lobes of chicken anterior pituitaries. GnRHR2 mRNA could easily be detected in both lobes of anterior pituitaries by qPCR (Figure 1E), while only an extremely weak expression of GnRHR1 mRNA was observed in the anterior pituitary (data not shown). This is similar to a previous report (Joseph et al., 2009); hence, it is likely that the action of $\mathrm{GnRH}$ on CART secretion is mediated by GnRHR2 predominantly expressed in chicken anterior pituitary.

\section{GnRH Induces CART mRNA Expression in Cultured Chick Pituitary Cells}

To further examine whether GnRHs could regulate pituitary $C A R T$ expression, the effect of $\mathrm{GnRH} 1 / 2$ on $C A R T$ expression was examined in cultured chick pituitary cells by qPCR. As shown in Figure 4A, GnRH1 could induce CART expression in a time-dependent manner, and the maximal effect was observed after 48-h treatment. Moreover, GnRH1 could stimulate CART expression dose-dependently with the minimal effective dose noted at $1 \mathrm{nM}$ (Figure 4B). Like GnRH1, GnRH2 could also induce CART expression in time- and dose-dependent manners (Figures 4C,D). In agreement with $\mathrm{GnRH}$ action on CART expression, GnRH receptor (GnRHR2, not GnRHR1) mRNA could easily be detected in cultured chick pituitary cells by RT-PCR (Figure 4E), supporting that GnRH-induced CART expression is likely mediated by GnRHR2.

\section{The Action of GnRH on Pituitary CART Expression and Secretion Are Mediated by Multiple Signaling Pathways Signaling Property of Chicken GnRHR1 and GnRHR2}

Although two GnRH receptors (GnRHR1 and GnRHR2) have been identified in chickens (Sun et al., 2001; Shimizu and Bedecarrats, 2006; Joseph et al., 2009), their downstream signaling pathways have not been fully characterized. Hence, in this study, we first examined the signaling property of chicken GnRHR1 and GnRHR2 using the three cell-based luciferase reporter assays established in our laboratory (pGL3NFAT-RE-luciferase, pGL4-SRE-luciferase, and pGL3-CREluciferease reporter assay systems) (Wang et al., 2007, 2012; Mo et al., 2015), which are capable of monitoring receptorstimulated calcium, MAPK/ERK, and cAMP/PKA signaling pathways, respectively.

As shown in Figure 5, using the three cell-based luciferase reporter assays, we found that GnRHR1/GnRHR2 expressed in $\mathrm{CHO}$ cells could be activated by chicken GnRH1 and GnRH2, and thus stimulate the luciferase activities dosedependently. This suggests that like mammalian GnRHR (Millar et al., 2004), both GnRHR1 and GnRHR2 are functionally coupled to the intracellular calcium, MAPK/ERK, and cAMP/ PKA signaling pathways.

Interestingly, we found that GnRHR1 could be potently activated by $\mathrm{GnRH} 2$, but not by GnRH1 (Figures 5A-C), indicating that GnRHR1 is a receptor specific to GnRH2. Unlike GnRHR1, GnRHR2 could be potently activated by both GnRH1 and GnRH2 (with GnRH2 being slightly more potent than GnRH1) (Figures 5D-F), suggesting that GnRHR2 is a receptor common for both $\mathrm{GnRH} 1$ and $\mathrm{GnRH} 2$. The $\mathrm{EC}_{50}$ values of GnRH1 and GnRH2 in activating the two GnRHRs are listed in Table 2. 
A

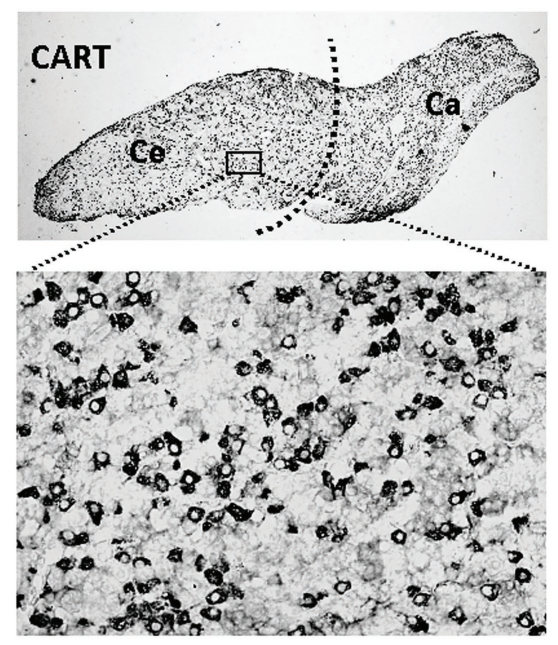

C

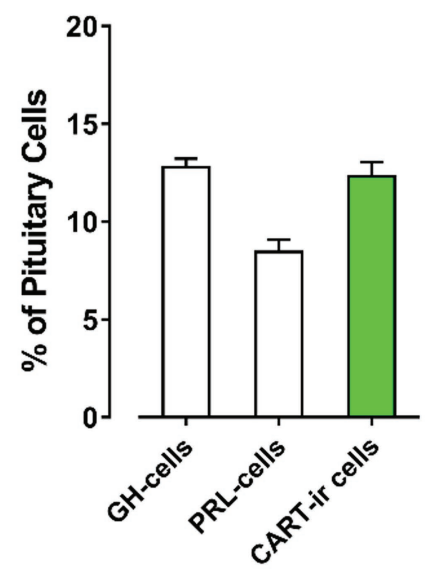

D

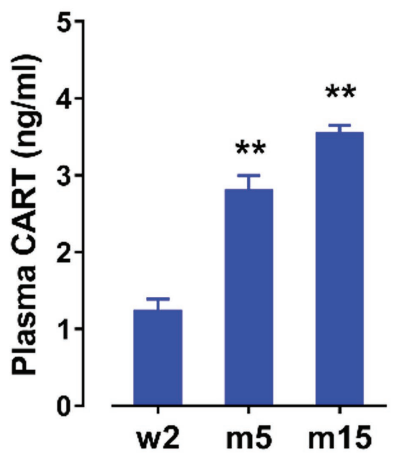

B
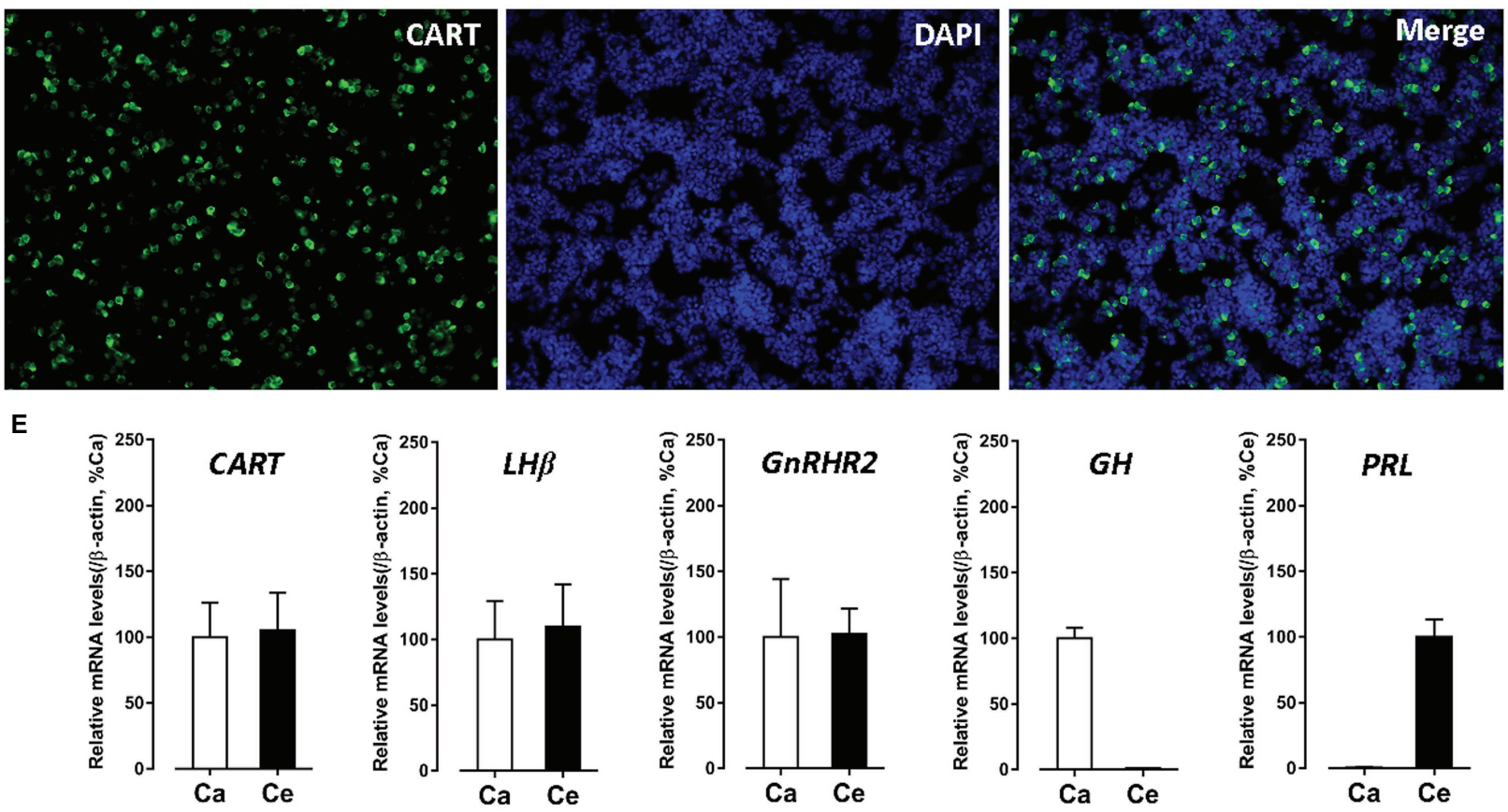

$\mathbf{F}$
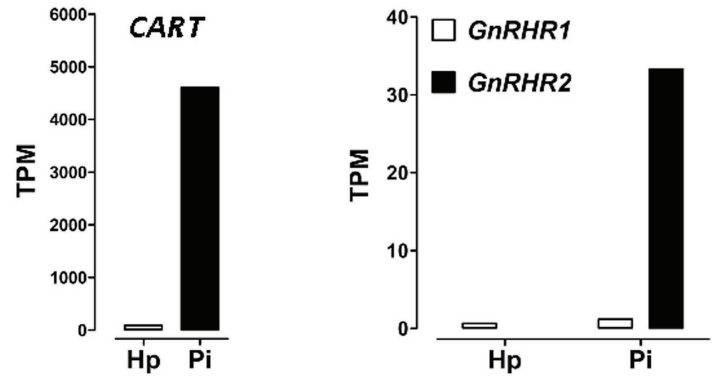

FIGURE 1 | (A) Immunohistochemical staining of cocaine- and amphetamine-regulated transcript (CART) in the anterior pituitary of adult male chickens. Histological examination was performed under bright-field illumination with a magnification at 40x (upper panel) and 400x (lower panel). CART-ir cells were found to be densely distributed in the cephalic (Ce) and caudal (Ca) lobes of anterior pituitaries. (B) Immunofluorescence staining of CART signal (green) in short-term cultured dispersed pituitary cells of adult male chickens. (C) Graph shows the relative proportion (positive cells/DAPI-stained nuclei \%) of GH-cells ( 12.8\%), PRL-cells $(\sim 8.5 \%)$, and CART-ir cells ( 12.3\%) in short-term cultured dispersed pituitary cells. Each data point in graphs represents mean \pm SEM of four replicates $(N=4)$ 
FIGURE 1 | (D) Enzyme-linked immunosorbent assay (ELISA) assay of plasma CART peptide levels in male chickens at the stages of 2-week-old (w2), 5-month-old (m5), and 15-month-old (m15). ${ }^{* *} p<0.01$ vs. w2. Each data point in graphs represents mean \pm SEM of four individuals $(N=4)$. (E) Quantitative real-time PCR (qPCR) assay of CART, LHB, GnRHR2, GH, and PRL mRNA levels in the Ce and Ca lobes of adult male chicken anterior pituitaries. Each data point represents mean \pm SEM of 10 individuals $(N=10)$. (F) RNA-Seq analyses of CART, GnRHR1, and GnRHR2 mRNA levels in the hypothalamus (Hp) and anterior pituitary (Pi) of 1-week-old male chicks.

\section{A}

CART 1 VPHYEKKFGQVPMCDAGEQCAVRKGARIGKLCDCPRGTSCNSFLLKCL 48
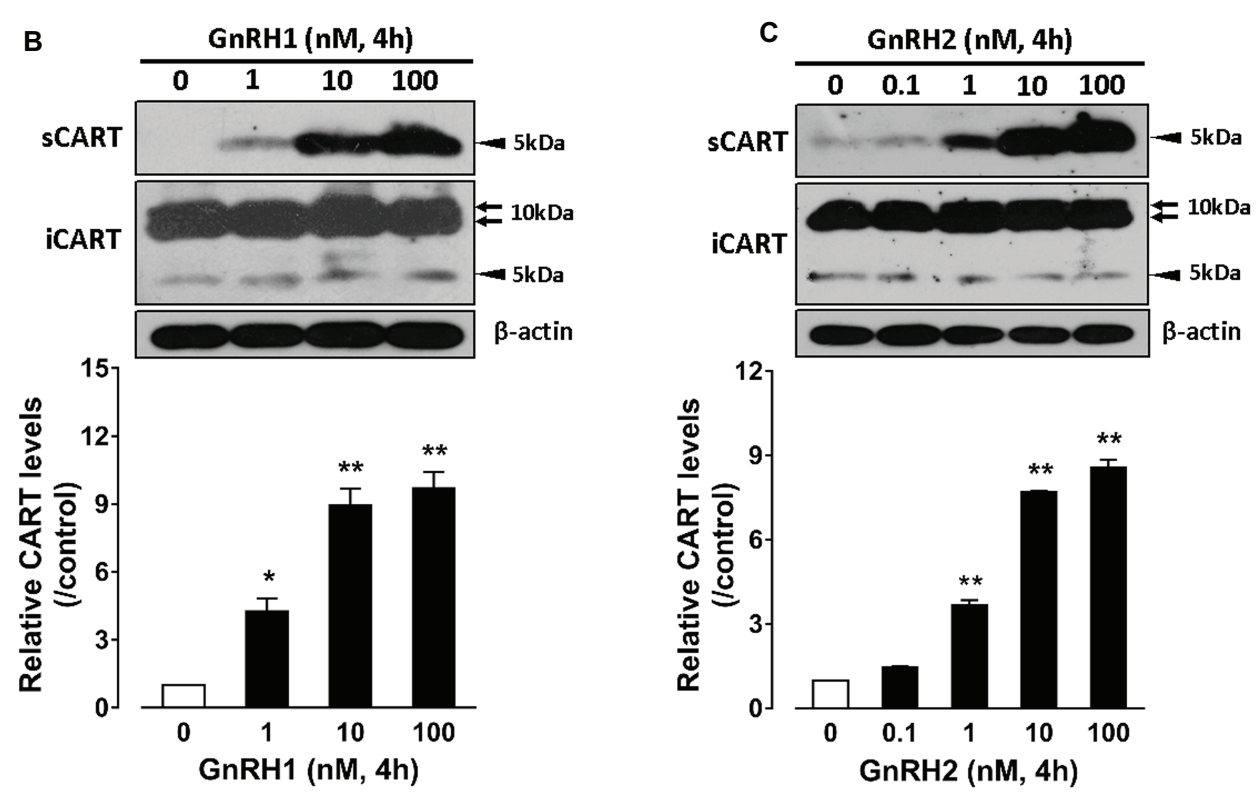

FIGURE 2 | (A) Sequence of mature chicken cocaine- and amphetamine-regulated transcript (CART) peptide ( $5 \mathrm{kDa})$ of 48 amino acids or 41 amino acids (shaded) cleaved from a large CART precursor of $\sim 10 \mathrm{kDa}$ (accession no.: KC249966) (Cai et al., 2015). (B,C) Western blot analyses showed that (B) chicken GnRH1 (1-100 nM, 4 h) and (B) GnRH2 (0.1-100 nM, 4 h) treatment could enhance the secretion of mature CART peptide into the incubation medium of chick anterior pituitaries incubated in vitro. The intracellular CART (iCART) and $\beta$-actin levels in the pituitary tissue lysate were also examined in parallel. The relative CART levels (sCART band, $5 \mathrm{kDa}$ ) in the incubation medium were quantified by densitometry, normalized by that of $\beta$-actin band in pituitary tissue lysate, and then expressed as fold increase of respective controls without $\mathrm{GnRH} 1 / \mathrm{GnRH} 2$ treatment. Each data point represents mean $\pm \mathrm{SEM}$ of three replicates $(N=3) .{ }^{*} p<0.05$; ${ }^{* *} p<0.01$ vs. respective control. Note: the three major CART bands including the two large CART bands $(\sim 10 \mathrm{kDa})$ and a small band $(\sim 5 \mathrm{kDa})$ were identified in chick pituitary tissue lysate (iCART), whereas only the small band $(\sim 5 \mathrm{kDa})$ representing the mature CART was identified in the incubation medium (sCART) of pituitaries. One representative set of Western blot is shown at the top of each graph.

\section{GnRH1-Induced CART Expression and Secretion Are Mediated by Multiple Signaling Pathways}

Since GnRHR2 (and GnRHR1) are coupled to multiple signaling pathways (Figure 5), pharmacological drugs targeting the components of these signaling pathways were used to examine their involvement in mediating the actions of GnRH on pituitary CART expression and secretion.

As shown in Figure 6, GnRH1-induced CART secretion could be significantly inhibited by U73122 [a phospholipase C (PLC) inhibitor, $20 \mu \mathrm{M}$ ], 2-APB (a specific inhibitor of IP3 receptor, which can block IP3-induced calcium mobilization, $100 \mu \mathrm{M}$ ), and nifedipine (a calcium channel blocker, $5 \mu \mathrm{M}$ ), respectively, in intact pituitaries incubated in vitro, suggesting that GnRH1-induced CART secretion is likely mediated by PLC/IP3/ $\mathrm{Ca}^{2+}$ signaling pathway and calcium channel coupled to GnRHR2. Moreover, we also found that U73122, thapsigargin [an inhibitor of sarco(endo)plasmic reticulum $\mathrm{Ca}^{2+}$-ATPase which can deplete intracellular calcium stores, $100 \mathrm{nM}$ ], calmidazolium (a calmodulin antagonist, $1 \mu \mathrm{M}$ ), KN62 [a specific inhibitor of $\mathrm{Ca}^{2+} /$ calmodulin-dependent protein kinase II (CaMKII), $5 \mu \mathrm{M}$ ], and nifedipine $(5 \mu \mathrm{M})$ could inhibit GnRH1induced CART mRNA expression in cultured chick pituitary cells (Figures 7A,B). These findings suggest that PLC/IP3/ $\mathrm{Ca}^{2+}$ signaling pathway and calcium channel coupled to GnRHR2 could also mediate GnRH1-induced CART mRNA expression.

Interestingly, we also found that calphostin $\mathrm{C}$ [a protein-kinase $\mathrm{C}$ (PKC) inhibitor, $200 \mathrm{nM}$ ] and PD98059 (an MEK inhibitor, $100 \mu \mathrm{M})$ could inhibit GnRH1-induced CART mRNA expression in cultured chick pituitary cells, while PMA, a PKC activator (100 nM), could mimic GnRH1 action (Figures 7B,C). These findings, together with the observation that GnRH1 treatment 


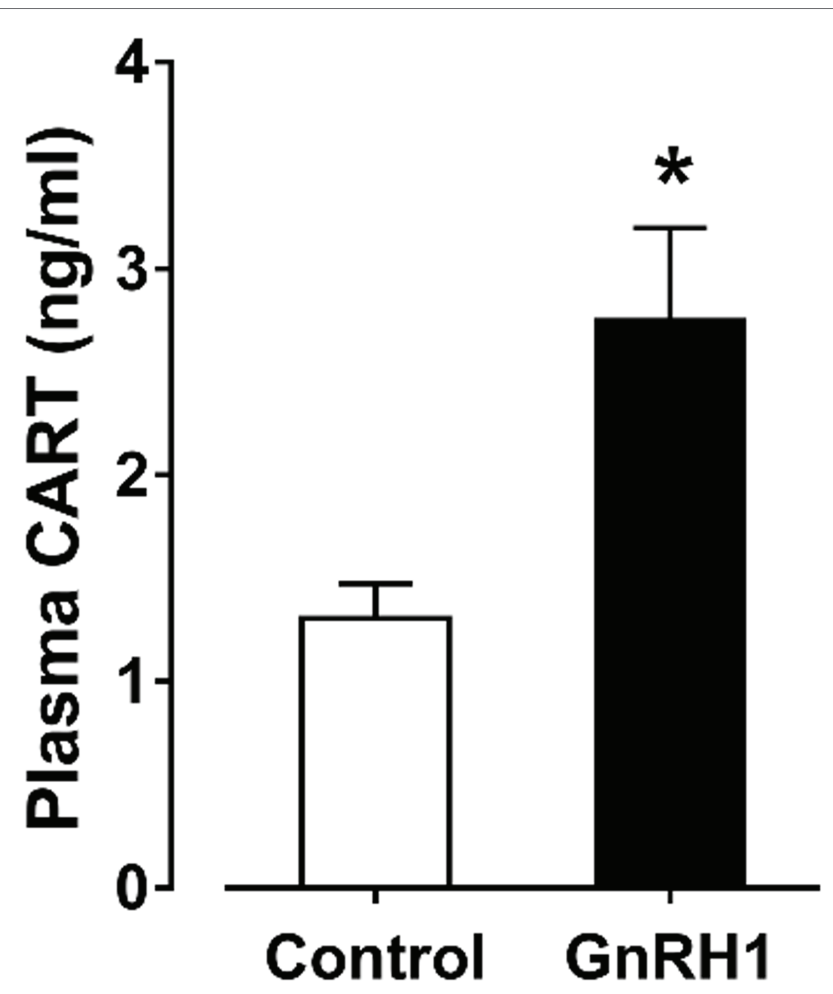

FIGURE 3 | Enzyme-linked immunosorbent assay (ELISA) analyses showed that intraperitoneal administration of $\mathrm{GnRH} 1$ ( $5 \mu \mathrm{g} / \mathrm{chick}, 30 \mathrm{~min})$ significantly elevated plasma cocaine- and amphetamine-regulated transcript (CART) peptide levels in vivo. Each data point represents mean \pm SEM of seven 19-day-old male individuals $(N=7)$. ${ }^{*} p<0.05$ vs. saline (control).

(10 nM, $10 \mathrm{~min}$ ) could enhance ERK2 phosphorylation (42 kDa) in cultured chick pituitary cells (Figure 7D), suggest the involvement of PKC/MEK/ERK2 signaling cascade in mediating GnRH1induced CART expression.

In addition, we found that forskolin [an adenlyate cyclase (AC) activator, $2 \mu \mathrm{M}$ ] treatment could mimic GnRH1 action on CART expression in cultured chick pituitary cells, while administration of either an AC inhibitor, MDL12330A $(20 \mu \mathrm{M})$, or a specific PKA inhibitor, H89 $(10 \mu \mathrm{M})$, could abolish GnRH1induced CART expression (Figure 8). These findings, together with the demonstration that GnRH1 (10 nM, $5 \mathrm{~min})$ could enhance CREB phosphorylation $(43 \mathrm{kDa})$ in cultured chick pituitary cells (Figure 8), suggest that AC/cAMP/PKA/CREB signaling pathway is involved in GnRH1-induced CART expression.

\section{DISCUSSION}

In this study, we revealed that a large proportion of CART-ir cells is present in chicken anterior pituitaries, and $\mathrm{GnRH}$ stimulates CART secretion and expression in vitro. In addition, CART is present in the plasma at physiological level and GnRH can significantly elevate the circulating CART levels in vivo. To our knowledge, our study provides the first collective evidence that
CART is a novel pituitary hormone, and its expression and secretion are controlled by the hypothalamic GnRH in chickens.

\section{Cocaine- and Amphetamine-Regulated Transcript (CART) Is a Pituitary Hormone in Chickens}

In our previous study, we found that chicken CART peptide is predominantly and abundantly expressed in the anterior pituitary (Cai et al., 2015). In this study, using IHC and IF, we further demonstrated that CART-ir cells are densely distributed throughout the anterior pituitary and they made up $\sim 12.3 \%$ of pituitary cells, which is comparable to the percentage of the other two hormone-producing cells $(\mathrm{GH}$ cells: $\sim 12.8 \%$; PRL cells: $~ 8.5 \%$ ) (Figure 1; Mo et al., 2017). The extremely high expression level of CART in chicken anterior pituitaries is substantiated by our transcriptome analysis, in which CART is shown to be predominantly expressed in chick anterior pituitary, but not in the hypothalamus (Figure 1F). All these findings suggest that CART is a novel pituitary hormone in chickens. Similarly, CART mRNA and protein has been reported to be localized in the anterior pituitary in mammals (Thim et al., 1999; Murphy et al., 2000). In rodents, CART-ir signals are localized in several hormone-producing cells, including gonadotrophs, lactotrophs, and corticotrophs (Kuriyama et al., 2004; Stanley et al., 2004; Kappeler et al., 2006; Smith et al., 2006). Consistent with the findings in chickens and mammals, CART mRNA is reported to be expressed in goldfish pituitaries (Volkoff and Peter, 2001). Taken together, this suggests that CART may act as a pituitary hormone involved in the regulation of many physiological processes in birds and mammals, and possibly across other vertebrates as well.

In agreement with the idea that CART is a pituitary hormone in chickens, a remarkably high concentration of plasma CART peptide $(1.2-3.5 \mathrm{ng} / \mathrm{ml} \approx 0.2-0.7 \mathrm{nM})$ was detected in chickens at pre-pubertal and sexually mature stages, with the concentration peak noted at the latter sexually mature stage (Figure 1). Since CART is predominantly expressed in the anterior pituitary (Figure 1), the high circulating CART level is most likely contributed by this tissue. This is consistent with the findings in mammals, in which a high concentration of plasma CART peptide is present $(\sim 0.05-0.25 \mathrm{ng} / \mathrm{ml}$ in rats; $0.075-0.125 \mathrm{ng} / \mathrm{ml}$ in monkeys; $0.15-$ $0.44 \mathrm{nM}$ in humans) (Stanley et al., 2004; Vicentic et al., 2004; Kappeler et al., 2006; Bech et al., 2008) and contributed mainly by the anterior pituitary and secondarily by other peripheral tissues (e.g., ovary, gut, and fat) (Stanley et al., 2004).

The identification of CART peptide as a pituitary hormone in chickens, together with the evidence on gastrin-releasing peptide (GRP) being a potential pituitary hormone presented in our recent study (Mo et al., 2017), undoubtedly stresses the importance on revisiting the basic concept of avian pituitary biology, i.e., the avian anterior pituitary, which has long been thought to produce six classic hormones (GH, PRL, ACTH, TSH, FSH, and LH) (Proudman et al., 1999; Scanes, 2015), secretes additional endocrine hormones including CART and GRP peptides. 

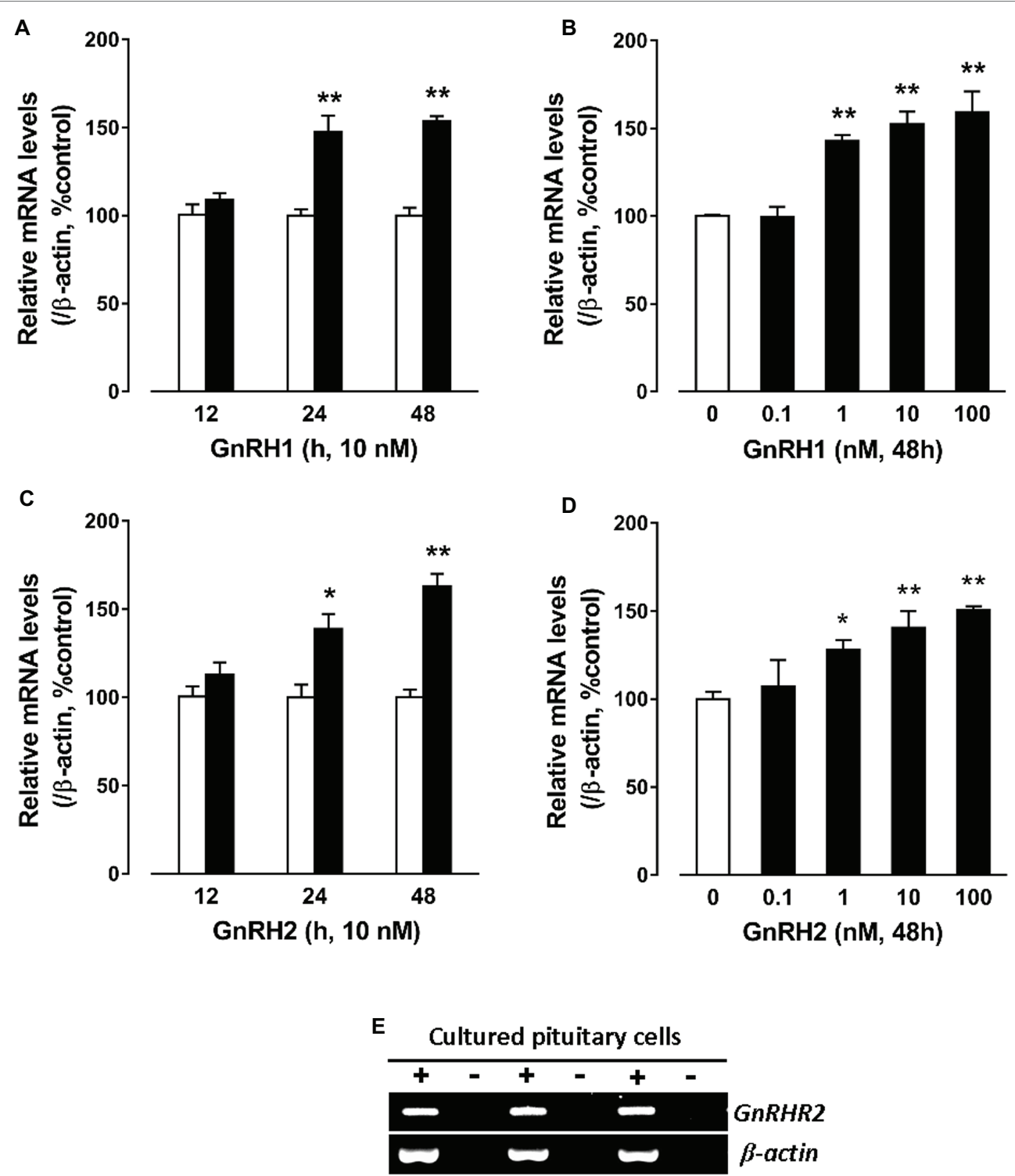

FIGURE 4 | Quantitative real-time PCR (qPCR) assay showing the effects of gonadotropin-releasing hormone (GnRH) on cocaine- and amphetamine-regulated transcript (CART) expression in cultured chick pituitary cells. (A,C) Time- and (B,D) dose-dependent effects of chicken GnRH1 and GnRH2 on CART mRNA expression in cultured chick pituitary cells. Pituitary cells were incubated with $\mathrm{GnRH} 1(10 \mathrm{nM})$ or $\mathrm{GnRH} 2(10 \mathrm{nM})$ for the duration as indicated or with increasing doses $(0-100 \mathrm{nM}, 48 \mathrm{~h})$ of GnRH1 or GnRH2 and subjected to qPCR assay of CART expression. The mRNA levels of CART were normalized by $\beta$-actin and expressed as the percentage of respective controls. Each value represents the mean \pm SEM of four replicates $(N=4)$. ${ }^{*} p<0.05$, ${ }^{* *} p<0.01$ vs. respective control. (E) RT-PCR detection of GnRHR2 expression in cultured chick pituitary cells (three replicates). RT was performed in the presence (+) or absence (-) of reverse transcriptase. Parallel PCR of $\beta$-actin was performed to serve as an internal control.

\section{GnRH1 Stimulates CART Secretion and Expression: Implications for the Roles of CART in Vertebrate Reproduction}

In this study, we found that CART-ir cells have a spatial distribution similar to that of gonadotropins (e.g., LH), which are distributed throughout both cephalic and caudal lobes (Figure 1; Proudman et al., 1999; Scanes, 2015). This points to the possibility that like LH (Chou et al., 1985; Hattori et al., 1986; Sharp et al., 1986), CART secretion and expression may be controlled by hypothalamic GnRH. In agreement with this idea, we found that GnRH can potently stimulate CART secretion and expression in vitro (Figures 2, 4), and elevate the plasma CART levels in vivo (Figure 3). Our findings clearly indicate that besides hypothalamic CRH (Mo et al., 2015), GnRH is another potent stimulator of pituitary CART secretion and expression in chickens. 

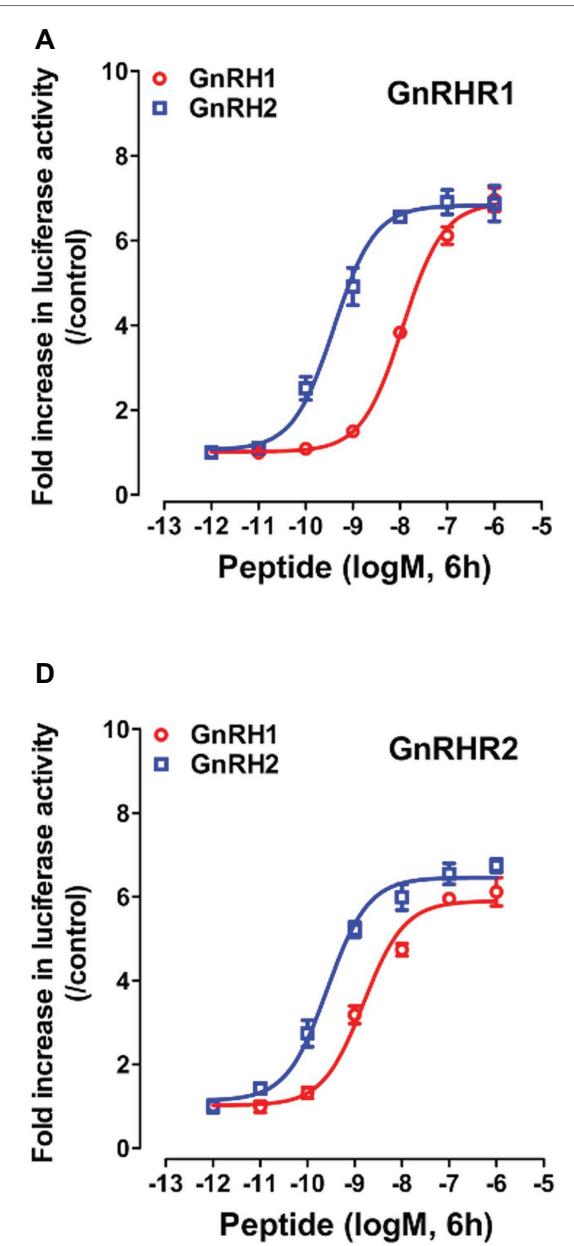
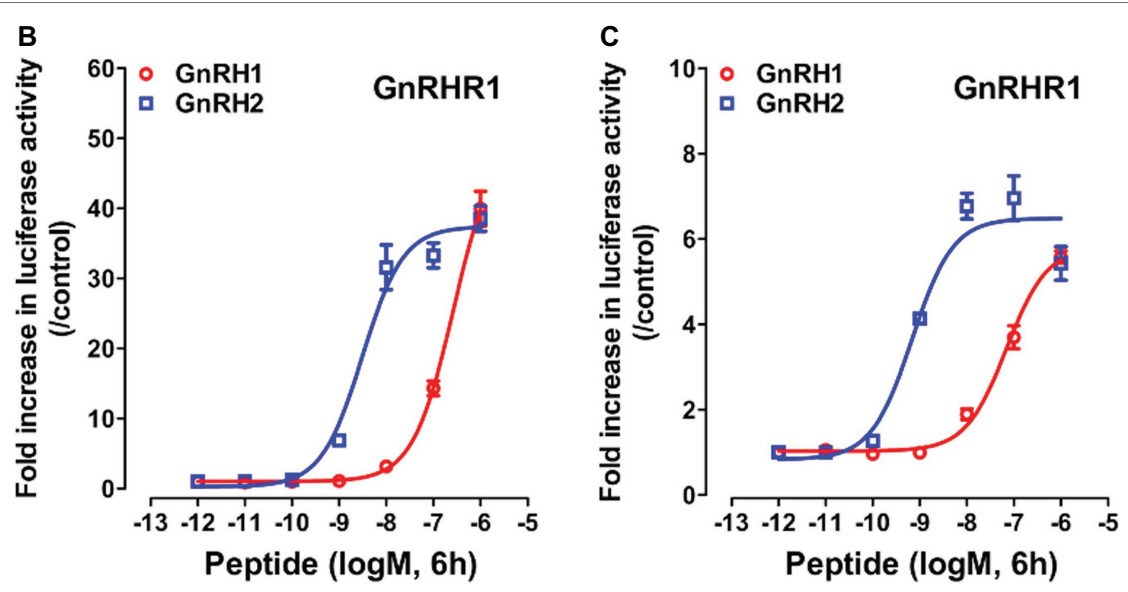

E

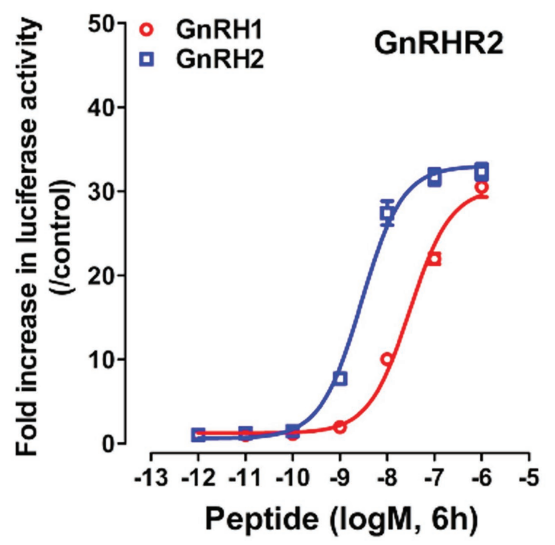

$\mathbf{F}$

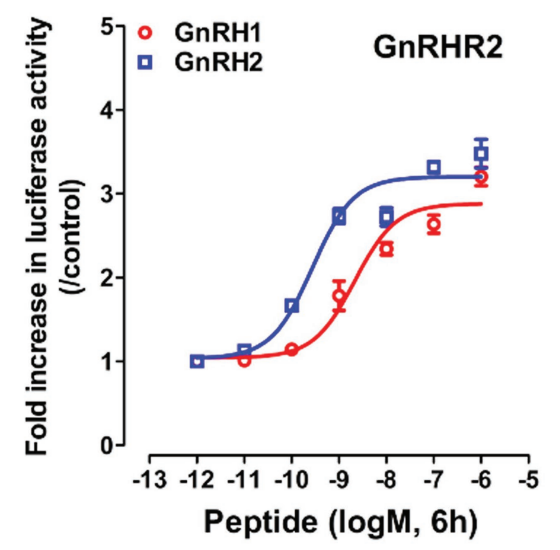

FIGURE 5 | Activation of chicken GnRHR1 or GnRHR2 expressed in CHO cells by chicken GnRH1 or GnRH2, monitored by pGL3-NFAT-RE-luciferase (A,D), pGL4-SRE-luciferase (B,E), and pGL3-CRE-luciferease (C,F) reporter systems. CHO cells co-transfected with empty pcDNA3.1(+) vector and pGL3-NFAT-REluciferase (/pGL4-SRE-luciferase or pGL3-CRE-luciferease) reporter construct were used as internal controls, and peptide treatment did not alter the luciferase activity of $\mathrm{CHO}$ cells at any concentration tested (data not shown). Each data point represents mean \pm SEM of four replicates $(N=4)$.

TABLE 2 | $\mathrm{EC}_{50}$ values of chicken $\mathrm{GnRH} 1$ and $\mathrm{GnRH} 2$ in activating different signaling pathways of $\mathrm{CHO}$ cells expressing chicken GnRHR1/GnRHR2.

\section{$\mathrm{EC}_{50}$ values (nM)}

\begin{tabular}{lcc}
\hline Peptide & GnRHR1 & GnRHR2 \\
\hline Calcium signaling pathway & 11.3 & \\
GnRH1 & 0.39 & 1.54 \\
GnRH2 & & 0.26 \\
MAPK/ERK signaling pathway & 270 & \\
GnRH1 & 3.10 & 29.9 \\
GnRH2 & & 2.84 \\
cAMP/PKA signaling pathway & 69.3 & 2.15 \\
GnRH1 & 0.69 & 0.27 \\
GnRH2 & & \\
\hline
\end{tabular}

Considering that the mRNA expression and pulsatile secretion of hypothalamic $\mathrm{GnRH}$ is reported to be negatively regulated by CRH in mammals (Kageyama, 2013), it is likely that in chickens, hypothalamic GnRH and CRH may regulate pituitary CART expression and secretion in a coordinated manner in vivo; however, this hypothesis still requires further elucidation.

It is reported that CART peptide is co-localized with FSH and LH in rat gonadotrophs (Kuriyama et al., 2004; Kappeler et al., 2006). Although GnRH-induced pituitary CART expression has not been reported in any other vertebrate species before, a previous study suggested that CART secretion is induced from rat pituitary upon perfusion with $\mathrm{GnRH}$ (Kappeler et al., 2006). Hence, it is tempting to hypothesize that hypothalamic GnRH may play a conserved role in the control of pituitary CART expression and secretion, and the subsequent circulating CART level in birds and mammals (Figure 9A). Nevertheless, this theory has yet been substantiated in mammals.

There has so far been a research gap regarding the role of circulating CART peptide in birds and mammals. In this study, we noted that plasma CART levels are significantly 


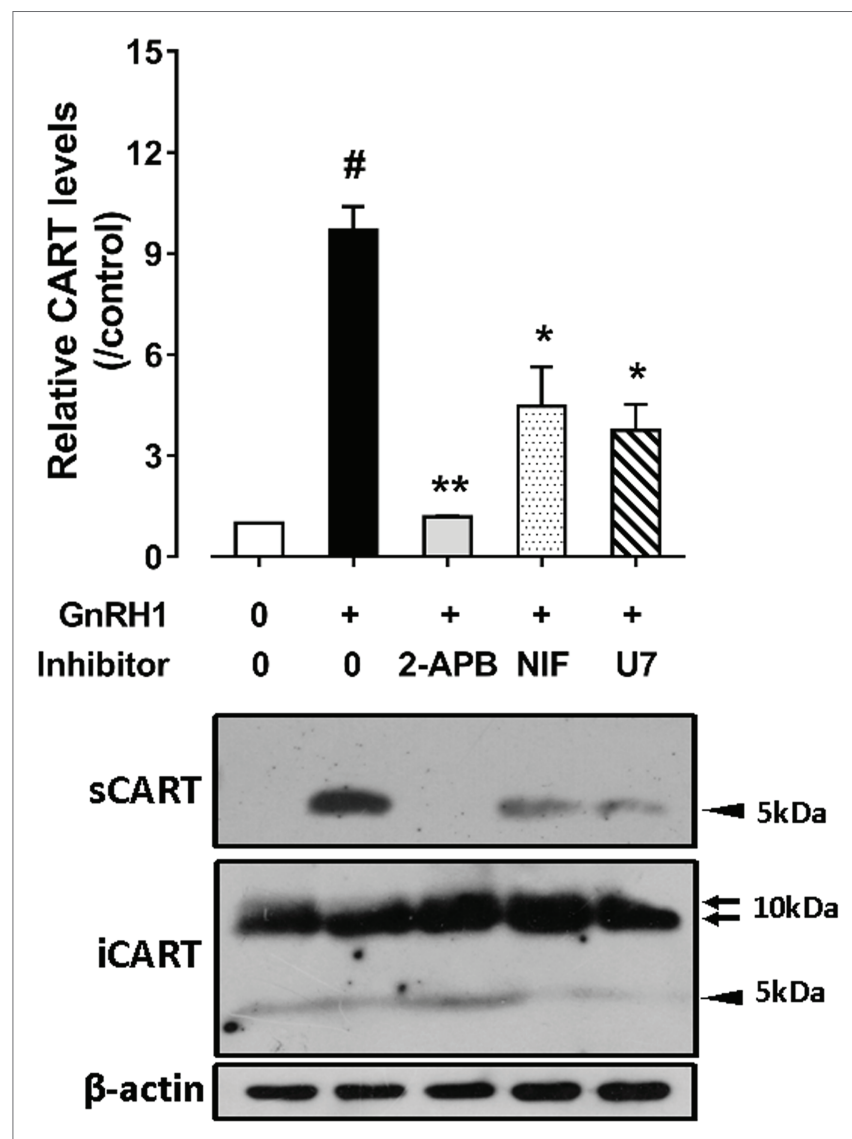

FIGURE 6 | Western blot detected the effect of chicken GnRH1 (5 nM, 4 h) on cocaine- and amphetamine-regulated transcript (CART) secretion in the incubation medium of chick pituitaries incubated in vitro in the presence of 2-APB $(100 \mu \mathrm{M})$, nifedipine (NIF, $5 \mu \mathrm{M})$, or U73122 (U7, $20 \mu \mathrm{M})$. The relative CART levels (sCART: $\sim 5 \mathrm{kDa}$ band) in the incubation medium were quantified by densitometry, normalized by that of $\beta$-actin band in pituitary tissue lysate, and then expressed as fold increase of controls without any treatment. ICART, intracellular CART, showed three major bands in pituitary tissue lysates. Each data point represents mean \pm SEM of three replicates $(N=3) .{ }^{\#} p<0.001$ vs. control; ${ }^{*} p<0.05,{ }^{* *} p<0.01$ vs. GnRH1 treatment (in the absence of drug). One representative set of Western blotting is shown at the bottom.

higher in sexually mature chickens than in immature chicks (Figure 1D). This is in line with the highest mRNA level of $C A R T$ detected in the anterior pituitary of sexually mature chickens in our recent study (Cai et al., 2015). Moreover, we demonstrated that $\mathrm{GnRH}$ can rapidly elevate plasma CART levels (Figure 3). Considering that $\mathrm{GnRH}$ is a pivotal player in the reproduction of birds and other vertebrate groups including the teleosts, frogs, reptiles, and mammals (Millar, 2005), it led us to speculate that circulating CART is likely involved in the control of reproduction, such as regulation of the development and/or functions of gonads (testis/ovary) via yet-to-be identified CART receptor(s) (Figure 9A; Sen et al., 2007; Rogge et al., 2008).

In mammals, there has been emerging evidence showing that CART may play a role in reproduction. In rodents, CART has been demonstrated to be a potent stimulator of both $\mathrm{GnRH}$ and kisspeptin (an up-regulator of $\mathrm{GnRH}$ neuron) neurons within the hypothalamus. CART-ir fibers are in close contact with GnRH cells and kisspeptin cells in rats, and this proximity may enhance both the amplitude and frequency of pulsatile GnRH secretion directly and indirectly (Lebrethon et al., 2000; de Roux et al., 2003; Irwig et al., 2004; True et al., 2013; Verma et al., 2014). In cows and ewes, CART is reported to be expressed in the ovary and present in ovarian follicular fluid (Kobayashi et al., 2004; Juengel et al., 2017). Moreover, in vitro experiments further supported that CART can inhibit basal and FSH-induced estradiol production in granulosa cells and may act as an important local autocrine/paracrine factor involved in the regulation of ovarian follicle development and steroidogenesis (Sen et al., 2007; Ma et al., 2016; Juengel et al., 2017). These pioneering findings, together with our convincing evidence showing that the expression and secretion of CART in chicken pituitary is regulated by $\mathrm{GnRH}$ (Figures 2-4), suggest that CART can act at different tier(s) of the hypothalamic-pituitary-gonadal axis (HPG) to regulate vertebrate reproduction (Kobayashi et al., 2004; True et al., 2013; Juengel et al., 2017).

\section{GnRH1-Induced CART Expression Is Mediated by Multiple Signaling Pathways Coupled to GnRHR2}

In this study, we found that GnRHR2 is abundantly expressed in chicken anterior pituitaries, whereas GnRHR1 is almost undetectable. Our finding agrees with our transcriptome analysis showing the predominant expression of GnRHR2 (not GnRHR1) in chick anterior pituitary (Figure 1F) and a recent observation that GnRHR2 is abundantly expressed in chicken pituitaries (Joseph et al., 2009). All these findings indicate that GnRH1-induced CART secretion and expression is primarily mediated by GnRHR2 (and not GnRHR1) expressed in chicken anterior pituitaries (Figure 9A). Meanwhile, the potent effect of GnRH on CART secretion, together with the similar spatial distribution patterns of CART, GnRHR2, and $L H \beta$ within anterior pituitaries (Figure 1E), also suggests that CART peptide is likely localized in gonadotrophs (e.g., LH cells) expressing GnRH receptor (Figure 9), as in mammals (Kuriyama et al., 2004; Kappeler et al., 2006).

To elucidate the downstream signaling pathways coupled to GnRHR2 (and GnRHR1), using the three established cell-based luciferase reporter assays, we further examined the signaling properties of the two GnRH receptors. We demonstrated that like mammalian GnRHR (Millar et al., 2004), chicken GnRHR2 (and GnRHR1) expressed in CHO cells is functionally coupled to the calcium, MAPK/ERK, and cAMP/PKA signaling pathways (Figure 5). Our finding partially agrees with previous studies, in which activation of chicken GnRHR2 (and GnRHR1) expressed in COS-7 cells or GH3 cells can increase intracellular IP3 levels and may stimulate the cAMP/PKA signaling pathway (Shimizu and Bedecarrats, 2006, 2010; Joseph et al., 2009). Considering that chicken GnRH1 (an ortholog of mammalian $\mathrm{GnRH}$ ), and not $\mathrm{GnRH} 2$, is present in the median eminence and directly involved in the control of LH secretion via GnRHR2 expressed in the chicken anterior 

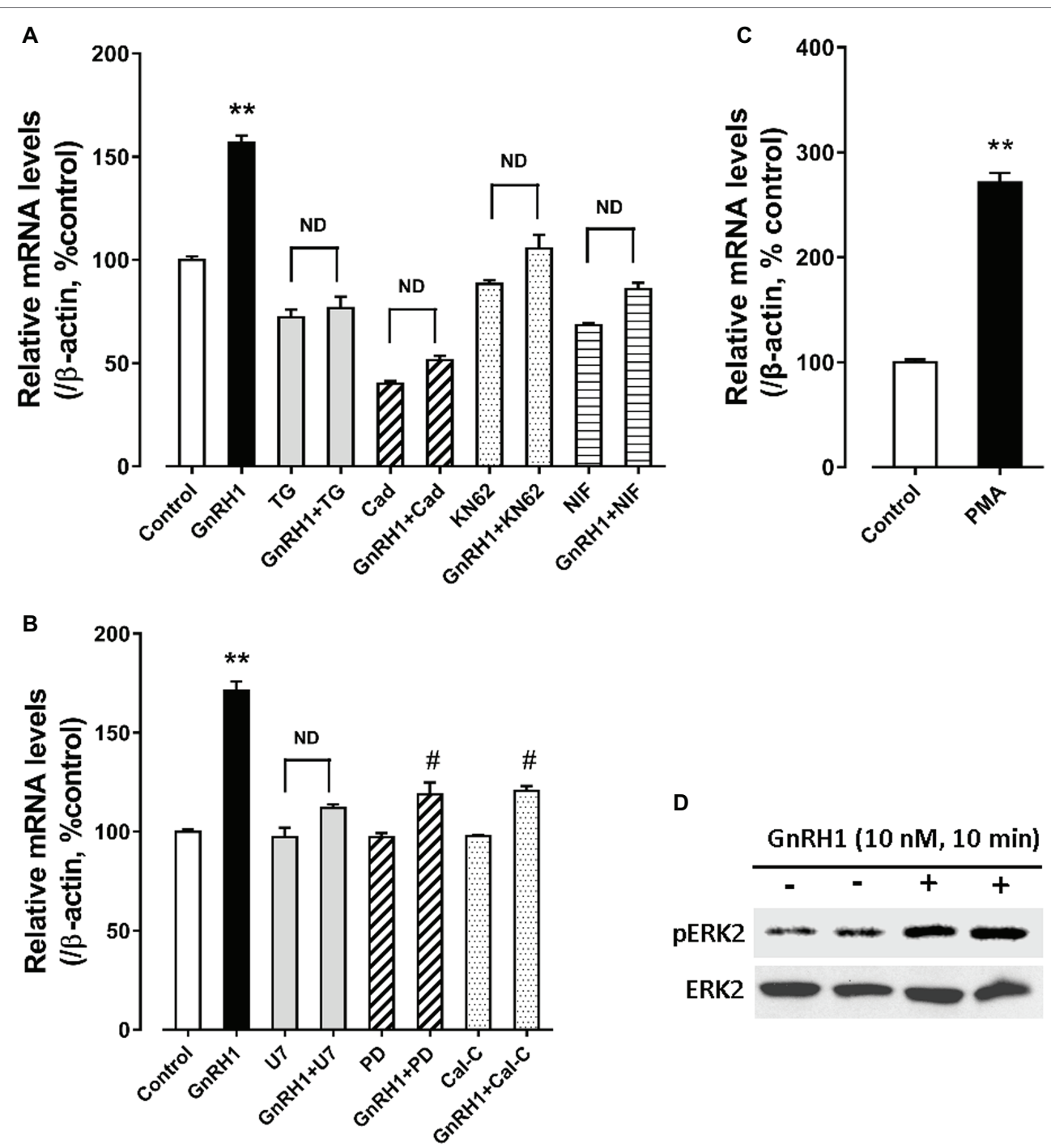

D

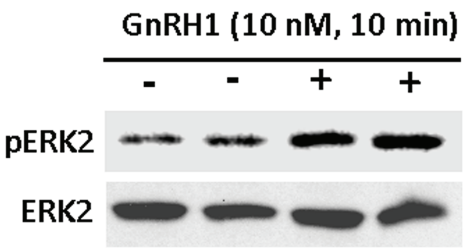

FIGURE 7 | (A) Effect of GnRH1 (10 nM, 24 h) on cocaine- and amphetamine-regulated transcript (CART) mRNA expression in cultured chick pituitary cells in the presence or absence of thapsigargin (TG, $100 \mathrm{nM}$ ), calmidazolium (Cad, $1 \mu \mathrm{M})$, KN62 (5 $\mu \mathrm{M})$ or nifedipine (NIF, $5 \mu \mathrm{M})$, respectively. (B) Effect of GnRH1 (10 nM, $24 \mathrm{~h}$ ) on CART mRNA expression in cultured chick pituitary cells in the presence or absence of U73122 (U7, $20 \mu \mathrm{M})$, PD98059 (PD, $100 \mu \mathrm{M})$, or calphostin C (Cal-C, $100 \mathrm{nM})$, respectively. (C) Effect of PMA (1 $\mu \mathrm{M}, 48 \mathrm{~h})$ on CART expression in cultured chick pituitary cells. The cells were treated for 24/48 h before RNA extraction and subjected to quantitative real-time PCR (qPCR) assay of CART mRNA levels. "ND" indicates no statistical difference between the two groups. Each data point represents mean \pm SEM of four replicates $(N=4)$. ${ }^{* \star} p<0.01$ vs. control; ${ }^{*} p<0.01$ vs. GnRH1 treatment (in the absence of drug). (D) Western blot showed that GnRH1 treatment (10 nM, $10 \mathrm{~min}$ ) could enhance ERK2 phosphorylation (pERK2) in cultured chick pituitary cells. Total ERK2 in cell lysates was also examined and used as internal controls. Note: only a single band for pERK2 or total ERK2 (42 kDa) was detected in cell lysate, because ERK1 gene is lost in chicken genome (Gerilechaogetu et al., 2009). The representative sets of independent experimental duplicates are shown here.

pituitary (Sharp et al., 1990; Joseph et al., 2009), the high potency of GnRH1 in activating GnRHR2 (Table 2) also hints of the potential physiological importance of GnRH1-GnRHR2 signaling in the regulation of gonadotropin secretion and reproduction in chickens (Sharp et al., 1990; Joseph et al., 2009).

Using intact pituitaries or cultured pituitary cells, we demonstrated that $\mathrm{Ca}^{2+}, \mathrm{PKC} / \mathrm{MEK} / \mathrm{ERK} 2$, and AC/cAMP/ PKA/CREB signaling pathways coupled to GnRHR2 could mediate GnRH1-induced CART expression and secretion, since inhibition or activation of these signaling pathways could block or mimic the GnRH1 action (Figure 9B). Our findings partially agree with the previous reports in mammals, in which the $\mathrm{Ca}^{2+}$ signaling pathway has been shown to regulate $C A R T$ expression in pituitary cells or non-pituitary cells, via the use of pharmacological drugs including ionomycin and inhibitors of calmodulin and CaMKII (Jones et al., 2009). Moreover, PMA, a PKC activator, enhances CART mRNA expression in ovine pars tuberalis cells (Barrett et al., 2001). In addition, the CART mRNA levels are enhanced by an AC activator or a CAMP analog, and their stimulatory effect is abolished by $\mathrm{H} 89$ in rat GH3 cells (Barrett et al., 2001). 

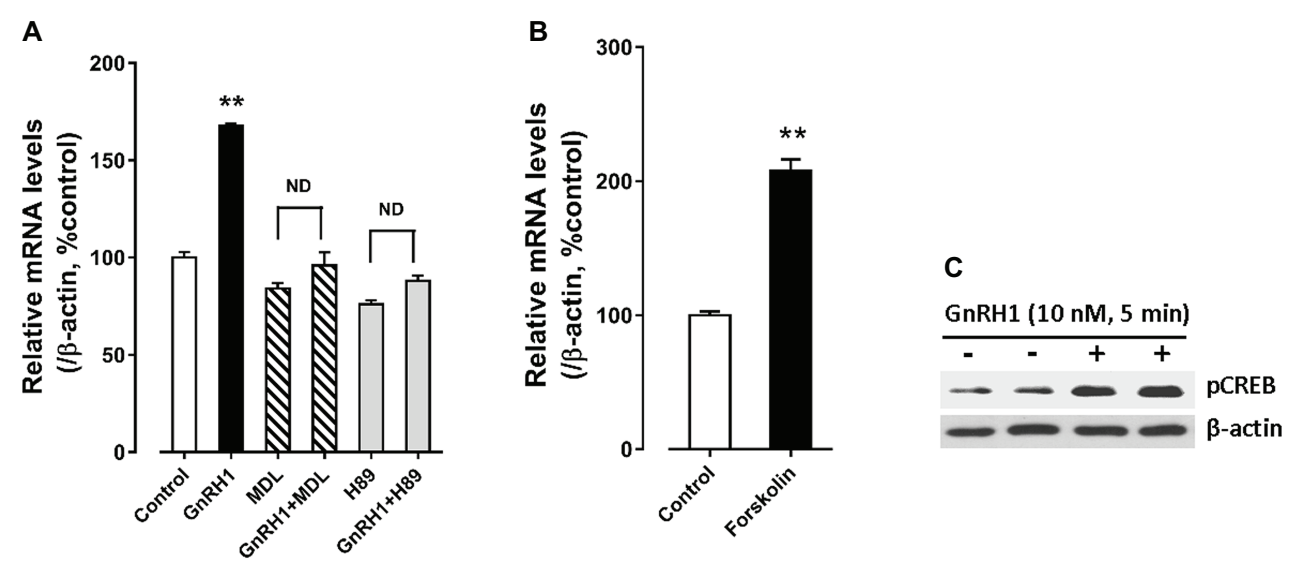

FIGURE 8 | (A) Effects of MDL12330A (MDL, $20 \mu \mathrm{M}$ ) and H89 (10 $\mu \mathrm{M})$ on GnRH1 (10 nM, 24 h)-induced CART mRNA expression. (B) Effect of forskolin (2 $\mu \mathrm{M}$, $24 \mathrm{~h}$ ) on basal CART mRNA expression. "ND" indicates no statistical difference between the two groups. Each data point represents mean \pm SEM of four replicates $(N=4) .{ }^{* *} p<0.01$ vs. control. (C) Western blot showed that GnRH1 (10 nM, 5 min) could enhance CREB phosphorylation (pCREB) in cultured chick pituitary cells. The $\beta$-actin in cell lysates were also examined and used as internal controls. The representative sets of independent experimental duplicates are shown here.
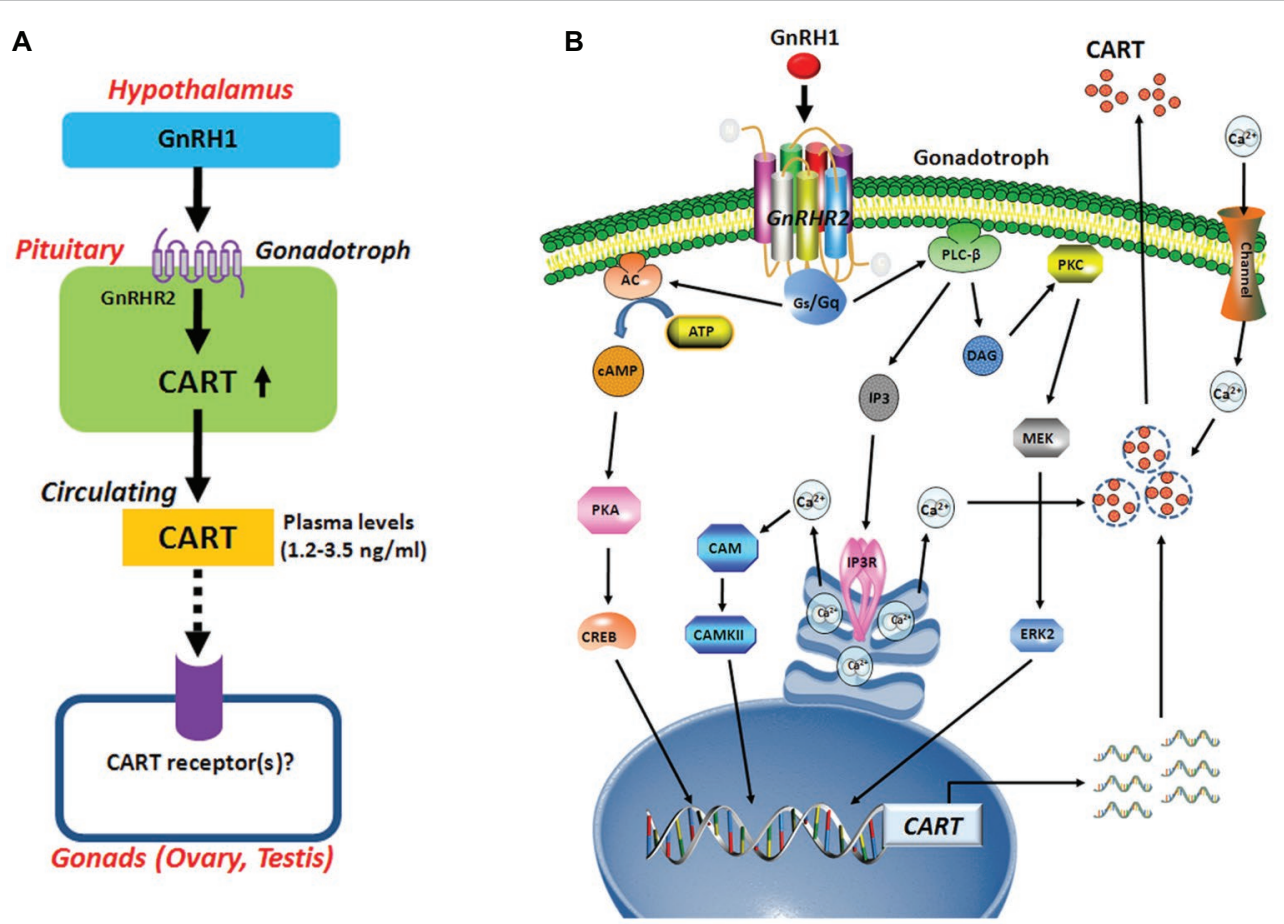

FIGURE 9 | (A) Hypothetic model for gonadotropin-releasing hormone (GnRH)-induced pituitary cocaine- and amphetamine-regulated transcript (CART) expression and secretion, which may act on chicken gonads (ovaries/testes) via an endocrine route. In this model, CART is a novel pituitary hormone, and its secretion into the circulation is potently stimulated by hypothalamic GnRH1 (an ortholog of mammalian $\mathrm{GnRH}$ ), suggesting that the development and functions of gonads (ovaries/testes) are likely controlled by CART peptide secreted from the anterior pituitary via CART receptor(s), which has not been identified in vertebrates. (B) The signaling pathways involved in mediating GnRH1-induced CART expression and secretion in pituitary gonadotrophs. In this model, GnRH1 stimulates CART expression and/or secretion via activation of GnRHR2 coupled to calcium channel and multiple signaling pathways including Gq-PLC/IP3/Ca ${ }^{2+}$, PKC/MEK/ERK, and Gs-AC/PKA/cAMP signaling pathways.

All these findings support the involvement of intracellular PKC and $\mathrm{AC} / \mathrm{cAMP} / \mathrm{PKA}$ signaling pathways in the regulation of CART expression in birds and mammals.
In summary, we demonstrated that GnRH can potently stimulate pituitary CART secretion and expression, an action mediated by GnRHR2 coupled to $\mathrm{Ca}^{2+}$, PKC/MEK/ERK2, and 
cAMP/PKA signaling pathways (Figure 9). In line with this finding, GnRH1 can also elevate the plasma CART levels in vivo. To our knowledge, our study represents the first to build a clear concept that CART is a novel pituitary hormone and its expression, secretion, and plasma level are tightly controlled by hypothalamic GnRH in chickens. Evidence presented here also implies that CART peptide may play an active role in the HPG axis of vertebrate, which is a new facet of research that has long been neglected and is worthwhile exploring.

\section{ETHICS STATEMENT}

This study was carried out in accordance with the recommendations of the guidelines provided by the Animal Ethics Committee of Sichuan University. The protocol was approved by the Animal Ethics Committee of Sichuan University.

\section{REFERENCES}

Abels, M., Riva, M., Bennet, H., Ahlqvist, E., Dyachok, O., Nagaraj, V., et al. (2016). CART is overexpressed in human type 2 diabetic islets and inhibits glucagon secretion and increases insulin secretion. Diabetologia 59, 1928-1937. doi: 10.1007/s00125-016-4020-6

Barrett, P., Morris, M. A., Moar, K. M., Mercer, J. G., Davidson, J. A., Findlay, P. A., et al. (2001). The differential regulation of CART gene expression in a pituitary cell line and primary cell cultures of ovine pars tuberalis cells. J. Neuroendocrinol. 13, 347-352. doi: 10.1046/j.1365-2826.2001.00634.x

Bech, P., Winstanley, V., Murphy, K. G., Sam, A. H., Meeran, K., Ghatei, M. A., et al. (2008). Elevated cocaine- and amphetamine-regulated transcript immunoreactivity in the circulation of patients with neuroendocrine malignancy. J. Clin. Endocrinol. Metab. 93, 1246-1253. doi: 10.1210/jc.2007-1946

Bu, G., Lin, D., Cui, L., Huang, L., Lv, C., Huang, S., et al. (2016). Characterization of neuropeptide $\mathrm{B}(\mathrm{NPB})$, neuropeptide $\mathrm{W}(\mathrm{NPW})$, and their receptors in chickens: evidence for NPW being a novel inhibitor of pituitary GH and prolactin secretion. Endocrinology 157, 3562-3576. doi: 10.1210/ en.2016-1141

Cai, G., Mo, C., Huang, L., Li, J., and Wang, Y. (2015). Characterization of the two CART genes (CART1 and CART2) in chickens (Gallus gallus). PLoS One 10:e0127107. doi: 10.1371/journal.pone.0127107

Chou, H. F., Johnson, A. L., and Williams, J. B. (1985). Luteinizing hormone releasing activity of [Gln8]-LHRH and [His5, Trp7, Tyr8]-LHRH in the cockerel, in vivo and in vitro. Life Sci. 37, 2459-2465.

de Roux, N., Genin, E., Carel, J. C., Matsuda, F., Chaussain, J. L., and Milgrom, E. (2003). Hypogonadotropic hypogonadism due to loss of function of the KiSS1-derived peptide receptor GPR54. Proc. Natl. Acad. Sci. USA 100, 10972-10976. doi: 10.1073/pnas.1834399100

Douglass, J., McKinzie, A. A., and Couceyro, P. (1995). PCR differential display identifies a rat brain mRNA that is transcriptionally regulated by cocaine and amphetamine. J. Neurosci. 15, 2471-2481. doi: 10.1523/ JNEUROSCI.15-03-02471.1995

Elefteriou, F., Ahn, J. D., Takeda, S., Starbuck, M., Yang, X., Liu, X., et al. (2005). Leptin regulation of bone resorption by the sympathetic nervous system and CART. Nature 434, 514-520. doi: 10.1038/nature03398

Elias, C. F., Lee, C. E., Kelly, J. F., Ahima, R. S., Kuhar, M., Saper, C. B., et al. (2001). Characterization of CART neurons in the rat and human hypothalamus. J. Comp. Neurol. 432, 1-19. doi: 10.1002/cne.1085

Gautvik, K. M., de Lecea, L., Gautvik, V. T., Danielson, P. E., Tranque, P., Dopazo, A., et al. (1996). Overview of the most prevalent hypothalamusspecific mRNAs, as identified by directional tag PCR subtraction. Proc. Natl. Acad. Sci. USA 93, 8733-8738.

Gerilechaogetu, Hanieh, H., Abe, A., and Kondo, Y. (2009). Extracellular signalregulated kinase (ERK) activation in chicken heterophils stimulated with phorbol 12-myristate 13-acetate (PMA), formyl-methionylleucyl-phenylalanine

\section{AUTHOR CONTRIBUTIONS}

$\mathrm{CM}$ and $\mathrm{YW}$ conceived and designed the experiments and analyzed the data. CM, CL, LH, ZL, and JZ performed the experiments. CM, JL, and YW contributed reagents, materials, and analysis tools and wrote the paper.

\section{FUNDING}

This work was supported by grants from the National Natural Science Foundation of China (31572391, 31271325, 31771375, and 31772590), and the open access publication fees can also be supported by these grants. The National Natural Science Foundation of China aims to promote science and technology development.

(fMLP) and lipopolysaccharide (LPS). Anim. Sci. J. 80, 577-584. doi: 10.1111/j. 1740-0929.2009.00674.x

Hattori, A., Ishii, S., and Wada, M. (1986). Effects of two kinds of chicken luteinizing hormone-releasing hormone (LH-RH), mammalian LH-RH and its analogs on the release of LH and FSH in Japanese quail and chicken. Gen. Comp. Endocrinol. 64, 446-455.

Honda, K., Kamisoyama, H., Saneyasu, T., Sugahara, K., and Hasegawa, S. (2007). Central administration of insulin suppresses food intake in chicks. Neurosci. Lett. 423, 153-157. doi: 10.1016/j.neulet.2007.07.004

Huang, G., He, C., Meng, F., Li, J., Zhang, J., and Wang, Y. (2014). Glucagonlike peptide (GCGL) is a novel potential TSH-releasing factor (TRF) in chickens: (I) evidence for its potent and specific action on stimulating TSH mRNA expression and secretion in the pituitary. Endocrinology 155, 4568-4580. doi: 10.1210/en.2014-1331

Irwig, M. S., Fraley, G. S., Smith, J. T., Acohido, B. V., Popa, S. M., Cunningham, M. J., et al. (2004). Kisspeptin activation of gonadotropin releasing hormone neurons and regulation of KiSS-1 mRNA in the male rat. Neuroendocrinology 80, 264-272. doi: 10.1159/000083140

Jensen, P. B., Kristensen, P., Clausen, J. T., Judge, M. E., Hastrup, S., Thim, L. et al. (1999). The hypothalamic satiety peptide CART is expressed in anorectic and non-anorectic pancreatic islet tumors and in the normal islet of Langerhans. FEBS Lett. 447, 139-143. doi: 10.1016/S0014-5793(99)00291-4

Jones, D. C., Lakatos, A., Rogge, G. A., and Kuhar, M. J. (2009). Regulation of cocaine- and amphetamine-regulated transcript mRNA expression by calcium-mediated signaling in GH3 cells. Neuroscience 160, 339-347. doi: 10.1016/j.neuroscience.2009.02.051

Joseph, N. T., Morgan, K., Sellar, R., McBride, D., Millar, R. P., and Dunn, I. C. (2009). The chicken type III GnRH receptor homologue is predominantly expressed in the pituitary, and exhibits similar ligand selectivity to the type I receptor. J. Endocrinol. 202, 179-190. doi: 10.1677/JOE-08-0544

Juengel, J. L., French, M. C., Quirke, L. D., Kauff, A., Smith, G. W., and Johnstone, P. D. (2017). Differential expression of CART in ewes with differing ovulation rates. Reproduction 153, 471-479. doi: 10.1530/REP-16-0657

Kageyama, K. (2013). Regulation of gonadotropins by corticotropin-releasing factor and urocortin. Front. Endocrinol. 4:12. doi: 10.3389/fendo.2013.00012

Kappeler, L., Gautron, L., Laye, S., Dantzer, R., Zizzari, P., Epelbaum, J., et al. (2006). Pituitary cocaine- and amphetamine-regulated transcript expression depends on the strain, sex and oestrous cycle in the rat. J. Neuroendocrinol. 18, 426-433. doi: 10.1111/j.1365-2826.2006.01435.x

Kobayashi, Y., Jimenez-Krassel, F., Li, Q., Yao, J., Huang, R., Ireland, J. J., et al. (2004). Evidence that cocaine- and amphetamine-regulated transcript is a novel intraovarian regulator of follicular atresia. Endocrinology 145, 5373-5383. doi: $10.1210 /$ en.2004-0283

Koylu, E. O., Couceyro, P. R., Lambert, P. D., Ling, N. C., DeSouza, E. B., and Kuhar, M. J. (1997). Immunohistochemical localization of novel CART peptides in rat hypothalamus, pituitary and adrenal gland. J. Neuroendocrinol. 9, 823-833. 
Kristensen, P., Judge, M. E., Thim, L., Ribel, U., Christjansen, K. N., Wulff, B. S., et al. (1998). Hypothalamic CART is a new anorectic peptide regulated by leptin. Nature 393, 72-76. doi: 10.1038/29993

Kuriyama, G., Takekoshi, S., Tojo, K., Nakai, Y., Kuhar, M. J., and Osamura, R. Y. (2004). Cocaine- and amphetamine-regulated transcript peptide in the rat anterior pituitary gland is localized in gonadotrophs and suppresses prolactin secretion. Endocrinology 145, 2542-2550. doi: 10.1210/en.2003-0845

Lebrethon, M. C., Vandersmissen, E., Gerard, A., Parent, A. S., and Bourguignon, J. P. (2000). Cocaine and amphetamine-regulated-transcript peptide mediation of leptin stimulatory effect on the rat gonadotropinreleasing hormone pulse generator in vitro. J. Neuroendocrinol. 12, 383-385. doi: 10.1046/j.1365-2826.2000.00497.x

Ma, X., Hayes, E., Prizant, H., Srivastava, R. K., Hammes, S. R., and Sen, A. (2016). Leptin-induced CART (cocaine- and amphetamine-regulated transcript) is a novel intraovarian mediator of obesity-related infertility in females. Endocrinology 157, 1248-1257. doi: 10.1210/en.2015-1750

Meng, F., Huang, G., Gao, S., Li, J., Yan, Z., and Wang, Y. (2014). Identification of the receptors for somatostatin (SST) and cortistatin (CST) in chickens and investigation of the roles of cSST28, cSST14, and cCST14 in inhibiting cGHRH1-27NH2-induced growth hormone secretion in cultured chicken pituitary cells. Mol. Cell. Endocrinol. 384, 83-95. doi: 10.1016/j.mce.2014.01.001

Millar, R. P. (2005). GnRHs and GnRH receptors. Anim. Reprod. Sci. 88, 5-28. doi: 10.1016/j.anireprosci.2005.05.032

Millar, R. P., Lu, Z. L., Pawson, A. J., Flanagan, C. A., Morgan, K., and Maudsley, S. R. (2004). Gonadotropin-releasing hormone receptors. Endocr. Rev. 25, 235-275. doi: 10.1210/er.2003-0002

Mo, C., Cai, G., Huang, L., Deng, Q., Lin, D., Cui, L., et al. (2015). Corticotropinreleasing hormone $(\mathrm{CRH})$ stimulates cocaine- and amphetamine-regulated transcript gene (CART1) expression through CRH type 1 receptor (CRHR1) in chicken anterior pituitary. Mol. Cell. Endocrinol. 417, 166-177. doi: 10.1016/j.mce.2015.09.007

Mo, C., Huang, L., Cui, L., Lv, C., Lin, D., Song, L., et al. (2017). Characterization of NMB, GRP and their receptors (BRS3, NMBR and GRPR) in chickens. J. Mol. Endocrinol. 59, 61-79. doi: 10.1530/JME-17-0020

Mortensen, A. H., and Camper, S. A. (2016). Cocaine-and amphetamine regulated transcript (CART) peptide is expressed in precursor cells and somatotropes of the mouse pituitary gland. PLoS One 11:e0160068. doi: 10.1371/journal. pone. 0160068

Murphy, K. G., Abbott, C. R., Mahmoudi, M., Hunter, R., Gardiner, J. V., Rossi, M., et al. (2000). Quantification and synthesis of cocaine- and amphetamine-regulated transcript peptide (79-102)-like immunoreactivity and mRNA in rat tissues. J. Endocrinol. 166, 659-668. doi: 10.1677/joe.0.1660659

Patro, R., Duggal, G., Love, M. I., Irizarry, R. A., and Kingsford, C. (2017). Salmon provides fast and bias-aware quantification of transcript expression. Nat. Methods 14, 417-419. doi: 10.1038/nmeth.4197

Proudman, J., Vandesande, F., and Berghman, L. (1999). Immunohistochemical evidence that follicle-stimulating hormone and luteinizing hormone reside in separate cells in the chicken pituitary. Biol. Reprod. 60, 1324-1328. doi: 10.1095/biolreprod60.6.1324

Rogge, G., Jones, D., Hubert, G. W., Lin, Y., and Kuhar, M. J. (2008). CART peptides: regulators of body weight, reward and other functions. Nat. Rev. Neurosci. 9, 747-758. doi: 10.1038/nrn2493

Scanes, C. (2015). "Pituitary gland" in Sturkie's avian physiology. 6th Edn. ed. C. G. Scanes (San Diego, California: Academic Press), 497e533.

Sen, A., Bettegowda, A., Jimenez-Krassel, F., Ireland, J. J., and Smith, G. W. (2007). Cocaine- and amphetamine-regulated transcript regulation of folliclestimulating hormone signal transduction in bovine granulosa cells. Endocrinology 148, 4400-4410. doi: 10.1210/en.2007-0332

Sharp, P. J., Dunn, I. C., and Talbot, R. T. (1987). Sex differences in the LH responses to chicken LHRH-I and -II in the domestic fowl. J. Endocrinol. 115, 323-331. doi: 10.1677/joe.0.1150323

Sharp, P. J., Sterling, R. J., Milton, R. C., and Millar, R. P. (1986). Effect of luteinising hormone releasing hormone and its analogues on plasma luteinising hormone concentrations in incubating bantam hens. Br. Poult. Sci. 27, 129-135. doi: $10.1080 / 00071668608416864$

Sharp, P. J., Talbot, R. T., Main, G. M., Dunn, I. C., Fraser, H. M., and Huskisson, N. S. (1990). Physiological roles of chicken LHRH-I and -II in the control of gonadotrophin release in the domestic chicken. J. Endocrinol. 124, 291-299. doi: 10.1677/joe.0.1240291
Shimizu, M., and Bedecarrats, G. Y. (2006). Identification of a novel pituitaryspecific chicken gonadotropin-releasing hormone receptor and its splice variants. Biol. Reprod. 75, 800-808. doi: 10.1095/biolreprod.105.050252

Shimizu, M., and Bedecarrats, G. Y. (2010). Activation of the chicken gonadotropininhibitory hormone receptor reduces gonadotropin releasing hormone receptor signaling. Gen. Comp. Endocrinol. 167, 331-337. doi: 10.1016/j.ygcen.2010.03.029

Smith, S. M., Vaughan, J. M., Donaldson, C. J., Fernandez, R. E., Li, C., Chen, A., et al. (2006). Cocaine- and amphetamine-regulated transcript is localized in pituitary lactotropes and is regulated during lactation. Endocrinology 147, 1213-1223. doi: 10.1210/en.2005-1392

Stanley, S. A., Murphy, K. G., Bewick, G. A., Kong, W. M., Opacka-Juffry, J., Gardiner, J. V., et al. (2004). Regulation of rat pituitary cocaine- and amphetamineregulated transcript (CART) by $\mathrm{CRH}$ and glucocorticoids. Am. J. Physiol. Endocrinol. Metab. 287, E583-E590. doi: 10.1152/ajpendo.00576.2003

Sun, Y. M., Flanagan, C. A., Illing, N., Ott, T. R., Sellar, R., Fromme, B. J., et al. (2001). A chicken gonadotropin-releasing hormone receptor that confers agonist activity to mammalian antagonists. Identification of D-Lys(6) in the ligand and extracellular loop two of the receptor as determinants. J. Biol. Chem. 276, 7754-7761. doi: 10.1074/jbc.M009020200

Tachibana, T., Takagi, T., Tomonaga, S., Ohgushi, A., Ando, R., Denbow, D. M., et al. (2003). Central administration of cocaine- and amphetamine-regulated transcript inhibits food intake in chicks. Neurosci. Lett. 337, 131-134. doi: 10.1016/S0304-3940(02)01321-6

Thim, L., Kristensen, P., Nielsen, P. F., Wulff, B. S., and Clausen, J. T. (1999). Tissue-specific processing of cocaine- and amphetamine-regulated transcript peptides in the rat. Proc. Natl. Acad. Sci. USA 96, 2722-2727.

True, C., Verma, S., Grove, K. L., and Smith, M. S. (2013). Cocaine- and amphetamineregulated transcript is a potent stimulator of GnRH and kisspeptin cells and may contribute to negative energy balance-induced reproductive inhibition in females. Endocrinology 154, 2821-2832. doi: 10.1210/en.2013-1156

Verma, S., Kirigiti, M. A., Millar, R. P., Grove, K. L., and Smith, M. S. (2014). Endogenous kisspeptin tone is a critical excitatory component of spontaneous GnRH activity and the GnRH response to NPY and CART. Neuroendocrinology 99, 190-203. doi: 10.1159/000365419

Vicentic, A. (2006). CART peptide diurnal variations in blood and brain. Peptides 27, 1942-1948. doi: 10.1016/j.peptides.2006.01.026

Vicentic, A., Dominguez, G., Hunter, R. G., Philpot, K., Wilson, M., and Kuhar, M. J. (2004). Cocaine- and amphetamine-regulated transcript peptide levels in blood exhibit a diurnal rhythm: regulation by glucocorticoids. Endocrinology 145, 4119-4124. doi: 10.1210/en.2003-1648

Volkoff, H., and Peter, R. E. (2001). Characterization of two forms of cocaineand amphetamine-regulated transcript (CART) peptide precursors in goldfish: molecular cloning and distribution, modulation of expression by nutritional status, and interactions with leptin. Endocrinology 142, 5076-5088. doi: 10.1210/endo.142.12.8519

Wang, Y., Li, J., Wang, C. Y., Kwok, A. H., and Leung, F. C. (2007). Identification of the endogenous ligands for chicken growth hormone-releasing hormone (GHRH) receptor: evidence for a separate gene encoding GHRH in submammalian vertebrates. Endocrinology 148, 2405-2416. doi: 10.1210/en.2006-1013

Wang, Y., Wang, C. Y., Wu, Y., Huang, G., Li, J., and Leung, F. C. (2012). Identification of the receptors for prolactin-releasing peptide (PrRP) and Carassius RFamide peptide (C-RFa) in chickens. Endocrinology 153, 1861-1874. doi: $10.1210 /$ en.2011-1719

Wierup, N., Bjorkqvist, M., Kuhar, M. J., Mulder, H., and Sundler, F. (2006). CART regulates islet hormone secretion and is expressed in the beta-cells of type 2 diabetic rats. Diabetes 55, 305-311. doi: 10.2337/diabetes.55.02.06. db04-1383

Conflict of Interest Statement: The authors declare that the research was conducted in the absence of any commercial or financial relationships that could be construed as a potential conflict of interest.

Copyright $\odot 2019$ Mo, Lv, Huang, Li, Zhang, Li and Wang. This is an open-access article distributed under the terms of the Creative Commons Attribution License (CC BY). The use, distribution or reproduction in other forums is permitted, provided the original author(s) and the copyright owner(s) are credited and that the original publication in this journal is cited, in accordance with accepted academic practice. No use, distribution or reproduction is permitted which does not comply with these terms. 